\title{
Neurosteroidogenesis Is Required for the Physiological Response to Stress: Role of Neurosteroid-Sensitive $\mathrm{GABA}_{\mathrm{A}}$ Receptors
}

\author{
Jhimly Sarkar, ${ }^{1}$ Seth Wakefield, ${ }^{2}$ Georgina MacKenzie, ${ }^{1}$ Stephen J. Moss, ${ }^{1}$ and Jamie Maguire ${ }^{1}$ \\ ${ }^{1}$ Department of Neuroscience, Tufts University School of Medicine, Boston, Massachusetts 02111, and ${ }^{2}$ Graduate Program in Neuroscience, Sackler School \\ of Graduate Biomedical Sciences, Tufts University, Boston, Massachusetts 02111
}

\begin{abstract}
The hypothalamic-pituitary-adrenal (HPA) axis, which mediates the body's response to stress, is largely under GABAergic control. Here we demonstrate that corticotropin-releasing hormone $(\mathrm{CRH})$ neurons are modulated by the stress-derived neurosteroid, tetrahydrodeoxycorticosterone (THDOC), acting on $\delta$ subunit-containing $\mathrm{GABA}_{\mathrm{A}}$ receptors $\left(\mathrm{GABA}_{\mathrm{A}} \mathrm{Rs}\right)$. Under normal conditions, THDOC potentiates the inhibitory effects of GABA on CRH neurons, decreasing the activity of the HPA axis. Counterintuitively, following stress, THDOC activates the HPA axis due to dephosphorylation of KCC2 residue Ser940, resulting in a collapse of the chloride gradient and excitatory GABAergic transmission. The effects of THDOC on CRH neurons are mediated by actions on $\mathrm{GABA}_{\mathrm{A}} \mathrm{R} \delta$ subunit-containing receptors since these effects are abolished in $\mathrm{Gabrd}^{-1-}$ mice under both control and stress conditions. Interestingly, blocking neurosteroidogenesis with finasteride is sufficient to block the stress-induced elevations in corticosterone and prevent stress-induced anxiety-like behaviors in mice. These data demonstrate that positive feedback of neurosteroids onto CRH neurons is required to mount the physiological response to stress. Further, $\mathrm{GABA}_{\mathrm{A}} \mathrm{R} \delta$ subunit-containing receptors and phosphorylation of KCC2 residue Ser940 may be novel targets for control of the stress response, which has therapeutic potential for numerous disorders associated with hyperexcitability of the HPA axis, including Cushing's syndrome, epilepsy, and major depression.
\end{abstract}

\section{Introduction}

Stress induces a physiological response which is mediated by the hypothalamic-pituitary-adrenal (HPA) axis. Corticotropinreleasing hormone $(\mathrm{CRH})$ release from the hypothalamus acts in the pituitary to signal the release of ACTH, which triggers the release of cortisol from the adrenal gland in humans (corticosterone in mice). The HPA axis is regulated by numerous brain regions, neurotransmitter systems, and the negative feedback of steroid hormones (for review, see Herman et al., 2003; Larsen et al., 2003; Ulrich-Lai and Herman, 2009). These inputs impinge on $\mathrm{CRH}$ neurons in the paraventricular nucleus (PVN), mediating the output of the HPA axis. Although $\mathrm{CRH}$ neurons receive a wide variety of inputs from diverse brain regions, their activity is ultimately regulated by GABAergic inhibition (Decavel and Van den Pol, 1990; for review, see Herman et al., 2004). However, very little is known about the

\footnotetext{
Received May 23, 2011; revised 0ct. 20, 2011; accepted 0ct. 23, 2011.

Author contributions: J.M. designed research; J.S., S.W., G.M., and J.M. performed research; S.J.M. contributed unpublished reagents/analytic tools; J.M. analyzed data; J.M. wrote the paper.

This project was funded by a Research Grant from the American Federation for Aging Research (AFAR) and NINDS Grant NS073574. The behavioral experiments were conducted in the Tufts Center for Neuroscience Research, P30 NS047243. We thank Dr. Istvan Mody for the Gabrd ${ }^{-1-}$ mice and Dr. Tarek Deeb for many critical discussions regarding chloride homeostasis and GABAergic inhibition.

Correspondence should be addressed to Dr. Jamie Maguire, Assistant Professor, Department of Neuroscience, Tufts University School of Medicine, 136 Harrison Avenue, SC205, Boston, MA 02111. E-mail: Jamie.Maguire@tufts.edu.

DOI:10.1523/JNEUROSCI.2560-11.2011

Copyright $(\odot) 2011$ the authors $\quad 0270-6474 / 11 / 3118198-13 \$ 15.00 / 0$
}

$\mathrm{GABA}_{\mathrm{A}} \mathrm{R}$ subtypes which regulate the activity of $\mathrm{CRH}$ neurons, and thus, the output of the HPA axis.

$\mathrm{GABA}_{\mathrm{A}} \mathrm{Rs}$ form heteropentameric assemblies from a potential pool of 19 different subunits: $\alpha 1-6, \beta 1-3, \gamma 1-3, \delta, \varepsilon, \theta, \pi$, and $\rho 1-3$ (Barnard et al., 1998; Whiting et al., 1999). Depending on their subunit composition, $\mathrm{GABA}_{\mathrm{A}}$ Rs have specific anatomical distributions (Pirker et al., 2000), physiological properties, and pharmacology (Hevers and Lüddens, 1998; Mody and Pearce, 2004). GABA ${ }_{A}$ Rs mediate two distinct forms of GABAergic inhibition, tonic and phasic, which are mediated by $\mathrm{GABA}_{\mathrm{A}}$ Rs with unique subunit assemblies (Farrant and Nusser, 2005). Extrasynaptically localized $\delta$ subunit-containing receptors mediate tonic GABAergic inhibition in many brain regions and confer neurosteroid sensitivity (Mihalek et al., 1999; Belelli et al., 2002; Brown et al., 2002; Wohlfarth et al., 2002; Spigelman et al., 2003). Interestingly, stress alters the expression of extrasynaptic $\mathrm{GABA}_{\mathrm{A}}$ Rs (Verkuyl et al., 2004), implicating these receptors in HPA axis regulation. Further, it has recently been demonstrated that rostral ventrolateral medulla-projecting parvocellular neurons in the PVN are regulated by a 4,5,6,7tetrahydroisoxazolo[5,4-c] pyridin-3-ol (THIP)-sensitive tonic current (Park et al., 2007), indicating that neurosteroid-sensitive, extrasynaptic $\delta$ subunit-containing $\mathrm{GABA}_{\mathrm{A}} \mathrm{Rs}$ may play a role in the regulation of these neurons (Boehm et al., 2006; Mortensen et al., 2010). Here we demonstrate for the first time that stress-derived neurosteroids modulate the physiological response to stress via actions on $\mathrm{GABA}_{\mathrm{A}} \mathrm{R} \delta$ subunit-containing receptors on $\mathrm{CRH}$ neurons. Neurosteroid regulation of CRH neurons represents a novel mechanism of HPA axis regulation. 
The inhibitory actions of GABA require the maintenance of a chloride gradient, which is primarily accomplished by the $\mathrm{K}^{+}$/ $\mathrm{Cl}^{-}$cotransporter, KCC2, in the adult brain (Rivera et al., 1999, 2005; Payne et al., 2003). The surface expression and activity of KCC2 are regulated by phosphorylation of KCC2 residue Ser940 (Lee et al., 2007). Further, activity-dependent dephosphorylation and downregulation of $\mathrm{KCC} 2$ results in excitatory actions of GABA (Lee et al., 2011). Here we demonstrate dephosphorylation of KCC2 residue Ser940 in the PVN following acute stress, resulting in decreased surface expression of KCC2 and excitatory actions of neurosteroids on CRH neurons. We propose a model in which neurosteroid actions on $\mathrm{GABA}_{\mathrm{A}} \mathrm{Rs}$ constitute a novel positive feedback mechanism onto CRH neurons thereby mediating the physiological response to stress.

\section{Materials and Methods}

\section{Animal handling}

Adult (3-month-old), male C57BL/6 and Gabrd ${ }^{-/-}$mice (Mihalek et al., 1999; a generous gift from Dr. Istvan Mody, University of California, Los Angeles, Los Angeles, CA) were housed at the Tufts University School of Medicine, Division of Laboratory Animal Medicine. Mice were housed in clear plastic cages (5 mice/cage) in a temperature- and humiditycontrolled environment with a $12 \mathrm{~h}$ light/dark cycle (light on at 7:00 A.M.) and ad libitum access to food and water. Animals were handled according to protocols approved by the Tufts University Institutional Animal Care and Use Committee.

\section{Western blot}

Western blot analysis was performed as previously described (Maguire et al., 2005, 2009; Maguire and Mody, 2007). Animals were anesthetized with isoflurane, killed by decapitation, and the PVN, hippocampus, and cerebellum were rapidly removed. The tissue was sonicated in homogenization buffer [containing (in mM): $10 \mathrm{NaPO}_{4}, 100 \mathrm{NaCl}, 10$ sodium pyrophosphate, $25 \mathrm{NaF}, 5$ EDTA, 5 EGTA, 2\% Triton X-100, 0.5\% deoxycholate, 1 sodium vanadate, $\mathrm{pH}$ 7.4) in the presence of protease inhibitors (Complete Mini, Roche, and fresh PMSF). The lysate was incubated on ice for $30 \mathrm{~min}$, and then the supernatant was collected following centrifugation at $14,000 \mathrm{rpm}$ for $10 \mathrm{~min}$ at $4^{\circ} \mathrm{C}$. Protein concentrations were determined using the DC Protein Assay (Bio-Rad). Total protein $\left(100 \mu \mathrm{g}\right.$ for the $\mathrm{GABA}_{\mathrm{A}} \mathrm{R} \delta$ subunit and $50 \mu \mathrm{g}$ for KCC2 and Ser940) was loaded onto a $10 \%$ SDS polyacrylamide gel, subjected to gel electrophoresis, transferred to an Immobilon-P membrane (Millipore), blocked in $10 \%$ nonfat milk, and probed with a monoclonal antibody specific for the $\mathrm{GABA}_{\mathrm{A}} \mathrm{R} \delta$ subunit (1:500, PhosphoSolutions 868-GDN), KCC2 (1:1000, Millipore), or Ser940 (1:1000, a generous gift from Dr. Steve Moss, Tufts University School of Medicine, Boston, MA). The blots were incubated with peroxidase-labeled anti-rabbit IgG (1:2000, GE Healthcare) and immunoreactive proteins were visualized using enhanced chemiluminescence (GE Healthcare). Optical density measurements were determined using the NIH ImageJ software.

For biotinylation experiments, slices containing the PVN were incubated in $1 \mathrm{mg} / \mathrm{ml}$ NHS-biotin (Pierce) in normal artificial CSF (nACSF) for $30 \mathrm{~min}$ on ice. The slices were then washed thoroughly with ice-cold nACSF and the total protein was isolated and quantified as described above. Total protein $(100 \mu \mathrm{g})$ was incubated with $50 \mu \mathrm{l}$ of streptavidin magnetic beads (Pierce) in $1 \mathrm{ml}$ of PBS overnight at $4^{\circ} \mathrm{C}$. The solution was centrifuged and the pellet was thoroughly washed and resuspended in 50 $\mu l$ of loading buffer. The proteins were eluted from the magnetic beads which were removed by centrifugation, and $20 \mu \mathrm{l}$ of the loading buffer/ protein solution was loaded onto a polyacrylamide gel and proteins visualized as described above.

\section{Immunohistochemistry}

Immunohistochemistry was performed as previously described (Maguire et al., 2009). Adult mice were administered $200 \mu \mathrm{l}$ of $10 \%$ fluorogold, intraperitoneally, 3-5 d before tissue harvesting. The mice were anesthetized with isoflurane, killed by decapitation, and the brain was rapidly removed. The brain was fixed by immersion fixation in $4 \%$ paraformal- dehyde overnight at $4^{\circ} \mathrm{C}$, cryoprotected in $10-30 \%$ sucrose, frozen at $-80^{\circ} \mathrm{C}$, and $40 \mu \mathrm{m}$ sections were prepared using a Leica cryostat. The sections were treated with $3 \% \mathrm{H}_{2} \mathrm{O}_{2} / \mathrm{MeOH}$ for 30 min, blocked with $10 \%$ normal goat serum for $1 \mathrm{~h}$, and probed with polyclonal antibodies specific for $\mathrm{GABA}_{\mathrm{A}} \mathrm{R} \delta$ subunit (1:500, Millipore AB9752) and HRPlabeled anti-rabbit IgG (ABC Elite, Vector Laboratories). DAB reactivity was visualized by light microscopy and optical density measurements were determined in the region of interest (fluorogold-labeled PVN) in serial sections in each animal using NIH ImageJ software. Sections were processed in parallel to ensure equivalent treatment of each experimental group.

\section{Generation of CRH-GFP reporter mice}

We engineered reporter mice which express GFP specifically in CRH neurons, enabling us to definitively identify this subset of neurons within the PVN. This reporter strain (CRH-GFP) was generated by crossing mTomato-GFP mice obtained from Jackson Laboratory (Stock \#007676) with CRH-Cre mice obtained from the Mutant Mouse Regional Research Center (MMRRC). GenSat provides in situ hybridization images of the stock $\mathrm{Tg}$ (Crh-cre)KN282Gsat mice that we obtained from the MMRRC (Fig. 1a), in which a thorough analysis of the CRH-Cre expression has been characterized and noted to "match in situ data and is supported by the literature" (Fig. 1a; GenSat; www.gensat.org). Further, the GenSat characterization of these mice indicates that the veracity of the CRH-Cre expression has been "Confirmed" which indicates that "multiple lines yield matching datasets that agree with the available literature" (GenSat website; www.gensat.org). These are the exact animals that we used for this study and thus we are confident that the Cre recombinase expression is specific for $\mathrm{CRH}$ neurons in this strain. To further confirm the specificity of Cre recombinase expression in CRH neurons, we crossed the $\mathrm{CRH}$-Cre mice with Rosa 26 reporter mice obtained from Jackson Laboratory (Stock \#003474) and expression in the PVN was confirmed using an X-gal staining assay kit (Genlantis) according to manufacturer's instructions (Fig. 1b). Nearly all $(99.9 \pm 0.1 \%)$ of LacZ-positive neurons in the PVN were also positive for fluorogold, whereas, $55.7 \pm 6.3 \%$ of fluorogold-positive neurons were LacZ-positive (Fig. 1c). We confirmed these results by enhancing the GFP expression in the CRH-GFP mice using a rabbit polyclonal anti-GFP antibody (Invitrogen, A6455) and an anti-rabbit Alexa Fluor488 secondary antibody (Invitrogen, A11034) (Fig. 1d). Nearly all the GFP-positive neurons in the PVN (98.4 $\pm 0.6 \%)$ were fluorogold-positive, whereas, only $58.9 \pm 18.6 \%$ of fluorogoldpositive neurons are also GFP-positive (Fig. 1c). Colocalization was determined using a correlation analysis based on the Pearson's coefficient with the Just Another Colocalization Plugin (Bolte and Cordelières, 2006) for ImageJ. The CRH expression in CRH-GFP neurons in the PVN was confirmed by post hoc single-cell PCR performed on the cellular contents harvested from our electrophysiology experiments as previously described (Browne et al., 2001; Hoyda et al., 2009). The cytoplasm was aspirated into the patch pipette taking careful measures to avoid aspiration of the nucleus. The cytoplasmic contents were then expelled into a $0.5 \mathrm{ml}$ PCR tube and $5 \mu \mathrm{l}$ of lysis buffer containing $2.9 \mu \mathrm{l}$ of DEPC-treated water, $1.4 \mu \mathrm{l}$ of BSA, $1.4 \mu \mathrm{l}$ of oligo-dT $(0.5 \mu \mathrm{g} / \mu \mathrm{l})$, and $1.4 \mu \mathrm{l}$ of RNasin $(40 \mathrm{U} / \mu \mathrm{l})$ was added to the harvested cytoplasm, heated to $70^{\circ} \mathrm{C}$ for $10 \mathrm{~min}$ and then placed on ice for $1 \mathrm{~min}$. Reverse transcriptase (RT)-PCR was performed by adding $15 \mu$ l of RT-PCR MasterMix containing $8 \mu$ l of DEPC-treated water, $2 \mu$ l of $10 \times$ first strand buffer, $2 \mu$ l of $\mathrm{MgCl}_{2}(25 \mathrm{~mm}), 2 \mu \mathrm{l}$ of DTT $(0.1 \mathrm{M}), 1 \mu \mathrm{l}$ of deoxynucleotide triphosphates $(10 \mathrm{~mm})$, and $0.7 \mu \mathrm{l}$ of SuperScript III reverse transcriptase (200 $\mathrm{U} / \mu \mathrm{l}$ ) and incubated at $42^{\circ} \mathrm{C}$ for $50 \mathrm{~min}$. The reaction mixture was incubated at $70^{\circ} \mathrm{C}$ for $15 \mathrm{~min}$ and RNase $\mathrm{H}(0.5 \mu \mathrm{l}$ of $2 \mathrm{U} / \mu \mathrm{l})$ was added and incubated at $37^{\circ} \mathrm{C}$ for $20 \mathrm{~min}$. All reagents were obtained from Invitrogen (SuperScript First Strand Synthesis Kit, 18080051). PCR amplification was performed by adding $25 \mu \mathrm{l}$ of $2 \times$ Multiplex Mastermix, $5 \mu \mathrm{l}$ of primer mix (2 $\mu \mathrm{M}$ each), $15 \mu \mathrm{l}$ of RNase-free water, and $5 \mu \mathrm{l}$ of cDNA template (Qiagen Multiplex PCR kit, 206143) and using the following cycling program: $94^{\circ} \mathrm{C}$ for $45 \mathrm{~s}, 60^{\circ} \mathrm{C}$ for $45 \mathrm{~s}$, and $72^{\circ} \mathrm{C}$ for $70 \mathrm{~s}$ for 50 cycles. The primers used in this study were previously described for single-cell PCR (Browne et al., 2001; Hoyda et al., 2009) and are listed in Table 1. Total brain, control cDNA was obtained from Clontech and used 


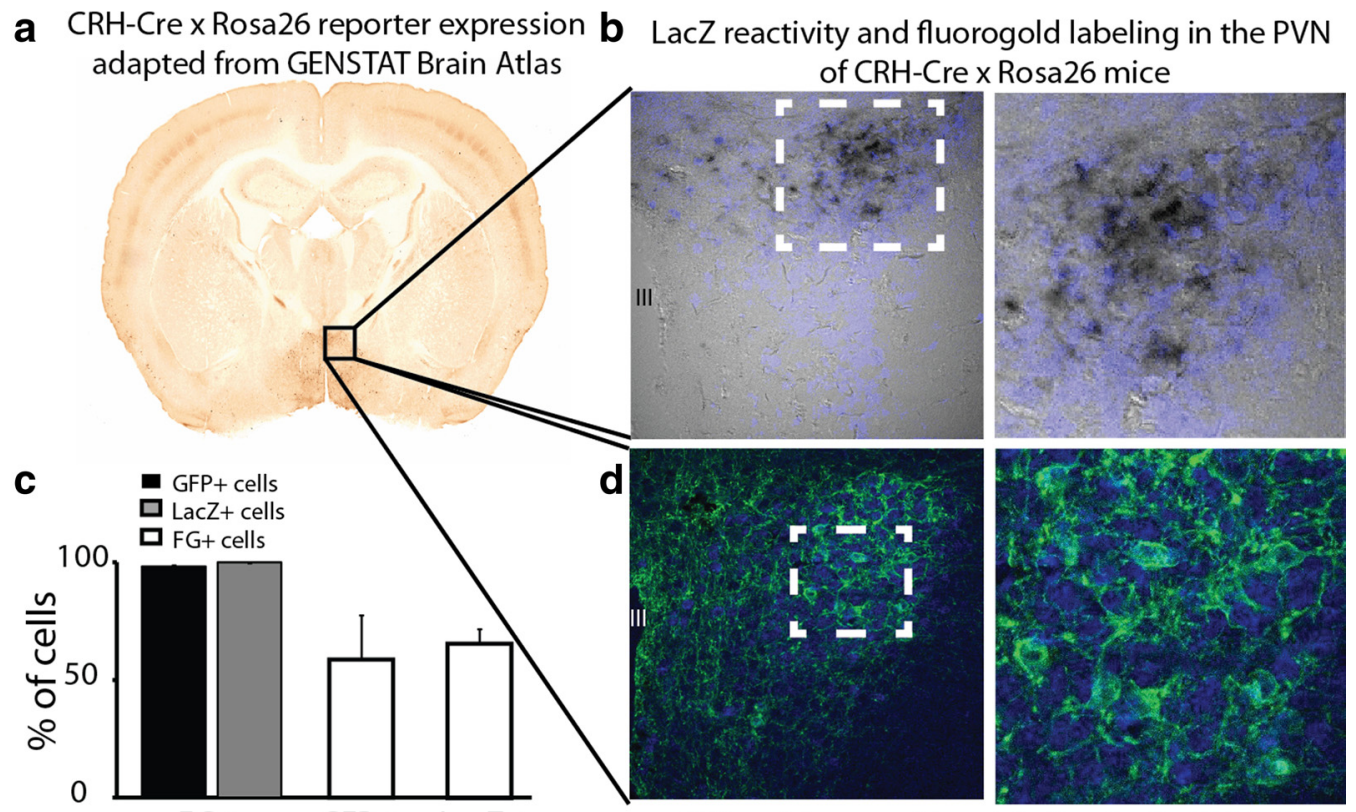

$\mathrm{FG}+\mathrm{GFP}+\mathrm{LacZ}+\quad$ GFP and fluorogold co-labeling in the PVN of

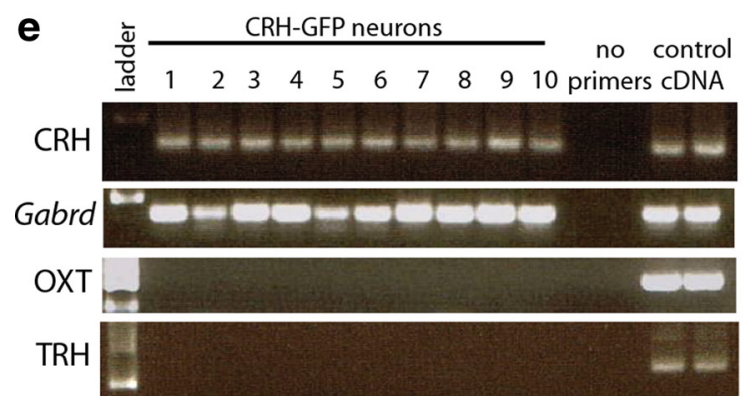
CRH-Cre x mTomato mice

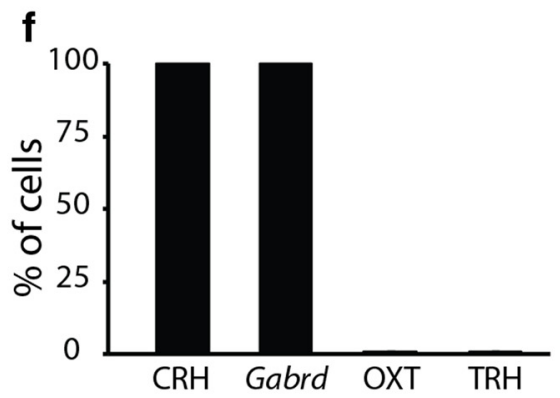

Figure 1. Characterization of CRH-GFP mice. $\boldsymbol{a}$, (re recombinase expression in CRH-Cre mice (image adapted from GenSat Brain Atlas). $\boldsymbol{b}$, LacZ reactivity (black) in the fluorogold-labeled PVN (purple) from offspring of CRH-Cre mice crossed with Rosa26 reporter mice. The magnified image demonstrates the colocalization of LacZ and fluorogold in neurons within the PVN (top right). $\boldsymbol{d}$, GFP immunoreactivity in CRH-GFP mice generated by crossing (RH-Cre mice with mTomato reporter mice. The magnified image shows the colocalization of GFP (green) and fluorogold (purple) in the CRH-GFP mice (bottom right). Nearly all the LacZ and GFP-positive neurons were also positive for fluorogold (c). In contrast, only 50\% of fluorogold-positive neurons were also positive for GFP or LacZ (c). $n=6$ mice per experimental group. $e$, Single-cell PCR products from individual CRH-GFP neurons in the PVN run on an ethidium bromide-stained $2 \%$ agarose gel. The primers used are shown in Table 1. Lanes 1-10 are the products from individual CRH-GFP neurons. "No primers" lanes are two samples in which the PCR did not contain specific primers. Control cDNA lanes are the product of PCRs using control CDNA as the template (Clontech). $f$, All of the CRH-GFP-positive neurons tested exhibited a PCR product for both CRH and Gabrd, but not oxytocin (OXT) or thyrotropin-releasing hormone (TRH). $n=10$ cells per experimental group.

Table 1. Primers for Single-cell PCR

\begin{tabular}{|c|c|c|c|c|c|}
\hline Gene & Primer & Position & Sequence & Product size (bp) & Reference \\
\hline \multirow[t]{3}{*}{ Corticotropin-releasing hormone } & \multirow[t]{3}{*}{ CRH } & F (outside) & GGGGAAAGGCAAAGAAAAGG & \multirow[t]{3}{*}{$140 \mathrm{bp}$} & \multirow[t]{3}{*}{ Hoyda et al., 2009} \\
\hline & & $R$ (outside) & GACAGAGCCACCAGCAGCAT & & \\
\hline & & $\mathrm{F}$ (nested) & GGAGAAGAGAAAGGAGAAGAGGAA & & \\
\hline \multirow[t]{3}{*}{$\mathrm{GABA}_{\mathrm{A}}$ receptor $\delta$ subunit } & \multirow[t]{3}{*}{ Gabrd } & F (outside) & GACTGCTGCAAAGGCTGCCGGGAAC & \multirow[t]{3}{*}{258 bp } & \multirow[t]{3}{*}{ Browne et al., 2001} \\
\hline & & $R$ (outside) & ACCACTGTGCTAACCATGACCACAC & & \\
\hline & & $\mathrm{F}$ (nested) & TTGAGTCTGGAACGGATGCCTC & & \\
\hline & \multirow{3}{*}{ OT } & $R$ (outside) & СCTCCGCTTCCGCAAGGCTTCTGGC & \multirow{3}{*}{$244 \mathrm{bp}$} & \multirow{3}{*}{ Hoyda et al., 2009} \\
\hline & & $\mathrm{F}$ (nested) & CTGCCCAGTCTCGCTTG & & \\
\hline & & $R$ (nested) & GCGAGGGCAGGTAGTTCTCC & & \\
\hline \multirow[t]{3}{*}{ Thyrotropin-releasing hormone } & \multirow[t]{3}{*}{ TRH } & F (outside) & AGAGGGGAGACTTGGGAGAA & \multirow[t]{3}{*}{$245 \mathrm{bp}$} & \multirow[t]{3}{*}{ Hoyda et al., 2009} \\
\hline & & $R$ (outside) & CTTTGCTTCACCAGGGTCTC & & \\
\hline & & $\mathrm{F}$ (nested) & ATTCATGGGCAGATGAGGAG & & \\
\hline
\end{tabular}


as a positive control. Reactions without specific primers were used as negative controls. The single-cell PCR products from CRH-GFP neurons confirm that the GFP-positive neurons are indeed CRH neurons. Our data demonstrate that $100 \pm 0.0 \%$ of CRH-GFP neurons express CRH mRNA, but do not express oxytocin $(0 \pm 0.0 \%)$ or thyrotropin-releasing hormone $(0 \pm 0.0 \%)$ (Fig. 1e,f). Consistent with the potential role of the $\mathrm{GABA}_{\mathrm{A}} \mathrm{R} \delta$ subunit in the regulation of CRH neurons, our data demonstrate that $100 \pm$ $0.0 \%$ of CRH-GFP neurons also express Gabrd (Fig. 1e,f).

\section{Electrophysiological recordings}

Adult (3-month-old) mice were anesthetized with isoflurane, decapitated, and the brain rapidly removed. Coronal sections, $350 \mu \mathrm{m}$ thick, including the PVN, were prepared in ice-cold nACSF using a Leica vibratome. The slices were stored oxygenated at $33^{\circ} \mathrm{C}$ for at least $1 \mathrm{~h}$ before recording. Slices containing hypothalamic PVN neurons were placed into a recording chamber maintained at $33^{\circ} \mathrm{C}$ (in-line heater, Warner Instruments) and perfused with nACSF containing (in mM): $126 \mathrm{NaCl}$, $26 \mathrm{NaHCO}_{3}, 1.25 \mathrm{NaH}_{2} \mathrm{PO}_{4}, 2.5 \mathrm{KCl}, 2 \mathrm{CaCl}_{2}, 2 \mathrm{MgCl}_{2}$, and 10 dextrose (300-310 mOsm). Adequate $\mathrm{O}_{2}$ tension and physiological $\mathrm{pH}$ (7.3-7.4) was maintained by continually bubbling the media with a gas mixture: $95 \% \mathrm{O}_{2} / 5 \% \mathrm{CO}_{2}$ and maintaining a high flow rate $(\geq 6 \mathrm{ml} / \mathrm{min})$ throughout the experiment. Tetrahydrodeoxycorticosterone (THDOC) (10 nM) and SR95531 (Gabazine, $\geq 200 \mu \mathrm{M}$ ) were added to the extracellular solution where indicated.

$\mathrm{CRH}$ neurons were visualized in the PVN by intraperitoneal fluorogold labeling to retrogradely label neurons projecting to the hypophyseal pituitary portal (Larsen et al., 2003) as well as using morphological and electrophysiological methods to identify parvocellular neurons in the PVN (Luther et al., 2002). These techniques have been used in other studies to identify CRH neurons (Hewitt et al., 2009; Kuzmiski et al., 2010). In addition to these methods, we have generated a reporter mouse (CRH-GFP mice) to aid in identification of CRH neurons in the PVN. Whole-cell recordings were performed on visually identified, fluorogoldlabeled and/or GFP-positive CRH neurons located in the medial part of the PVN. Intracellular recording solution contained (in mM): $140 \mathrm{CsCl}, 1$ $\mathrm{MgCl}_{2}, 10$ HEPES, $4 \mathrm{NaCl}$, 0.1 EGTA, $2 \mathrm{Mg}$-ATP, $0.3 \mathrm{Na}-\mathrm{GTP}(\mathrm{pH}=$ $7.25,280-290 \mathrm{mOsm}$ ) and electrodes with DC resistance of 5-8 M $\Omega$ were used for recording spontaneous IPSCs at $V_{\mathrm{H}}=-70 \mathrm{mV}$ in the wholecell, voltage-clamp configuration in the presence of $3 \mathrm{~mm}$ kynurenic acid. Tonic GABAergic currents were measured as previously described (Stell et al., 2003; Maguire et al., 2005, 2009; Maguire and Mody, 2007). Briefly, the mean current was measured during 10 ms epochs collected every $100 \mathrm{~ms}$ throughout the experiment. A Gaussian was fit to these points to determine the mean holding current in nACSF, in the presence of $10 \mathrm{nM}$ THDOC, and in the presence of saturating concentrations of SR95531. The difference in the holding current in the presence or absence of SR95531 is attributed to the tonic GABAergic current. Series resistance and whole-cell capacitance were continually monitored and compensated throughout the course of the experiment. Recordings were eliminated from data analysis if series resistance increased by $>20 \%$.

The firing rate of visually identified, GFP-positive CRH neurons was determined in the current-clamp configuration using an intracellular recording solution containing (in $\mathrm{mM}$ ): $130 \mathrm{~K}$-gluconate, $10 \mathrm{KCl}, 4 \mathrm{NaCl}$, 10 HEPES, 0.1 EGTA, 2 Mg-ATP, 0.3 Na-GTP (pH = 7.25, 280-290 $\mathrm{mOsm})$. The spontaneous firing rate was measured over a $5 \mathrm{~min}$ period in $\mathrm{nACSF}$ and over a $5 \mathrm{~min}$ period in the presence of $10 \mathrm{nM}$ THDOC.

The firing rate was also determined under perforated patch-clamp conditions in GFP-positive CRH neurons in the current-clamp $I=0$ configuration using an intracellular recording solution containing (in $\mathrm{mm}$ ): $130 \mathrm{~K}$-gluconate, $10 \mathrm{KCl}, 4 \mathrm{NaCl}, 10 \mathrm{HEPES}, 0.1$ EGTA, $2 \mathrm{Mg}$-ATP, $0.3 \mathrm{Na}-\mathrm{GTP}(\mathrm{pH}=7.25,280-290 \mathrm{mOsm}$ ) with $50 \mu \mathrm{g} / \mathrm{ml}$ gramicidin (ABCD, Sigma). Perforated patch recordings with gramicidin were used to maintain the native ionic gradients. The firing rate was recorded in the $I=0$ configuration to maintain the native resting membrane potential of the CRH neurons which was not statistically different between experimental groups. Access resistance of $<20 \mathrm{M} \Omega$ was achieved within $20-30$ min of establishing the G $\Omega$ seal under perforated patch-clamp conditions. Series resistance and capacitive transients were carefully monitored throughout the experiments to confirm the stability of the perforated patch. The firing rate was determined once the resting membrane potential stabilized. The spontaneous firing rate was measured for over a $5 \mathrm{~min}$ period in $\mathrm{nACSF}$ and over a $5 \mathrm{~min}$ period in the presence of $10 \mathrm{~nm}$ THDOC or $\geq 200 \mu \mathrm{M}$ SR95531. In addition, sIPSPs were measured under perforated patch-clamp conditions in control mice and mice subjected to acute restraint stress.

For all electrophysiology experiments, data acquisition was performed using a Molecular Devices Axopatch 200B and Powerlab hardware and software (ADInstruments).

\section{Microinfusions}

Adult C57BL/6 or $\mathrm{Gabrd}^{-/-}$mice were anesthetized with $100 \mathrm{mg} / \mathrm{kg}$ ketamine and $10 \mathrm{mg} / \mathrm{kg}$ xylazine until unresponsive to a foot pinch. A lengthwise incision was made along the scalp to expose the skull. A small burr hole was made over the PVN (coordinates: $-0.9 \mathrm{~mm}$ anterior/posterior, \pm 0.2 $\mathrm{mm}$ medial/lateral, $-4.65 \mathrm{~mm}$ dorsal/ventral). A $5 \mu \mathrm{l}$ Hamilton syringe was lowered above the PVN and $0.5 \mu$ l of either vehicle ( $0.5 \%$ cresyl violet) or 100 $\mathrm{nM} \mathrm{THDOC} \mathrm{(in} 0.5 \%$ cresyl violet) was slowly injected at a rate of $0.5 \mu \mathrm{l} / \mathrm{min}$. The syringe was left in place for at least $10 \mathrm{~min}$ before the slow removal of the syringe. Thirty minutes following the microinfusion, a blood sample was collected to determine the circulating concentration of corticosterone and compared with blood samples collected from the same animals $24 \mathrm{~h}$ before the microinfusion. Great care was taken to ensure that the corticosterone levels were measured at the same time of day $(\sim 12 \mathrm{pm})$ to prevent differences due to diurnal changes in corticosterone levels. The brain was removed, postfixed, cryoprotected, and cryostat sectioned to confirm the location of the microinfusion site in all experiments.

\section{Corticosterone measurements}

Whole blood was collected from experimental groups by submandibular bleed or trunk blood collection. Submandibular blood was collected $24 \mathrm{~h}$ before restraint stress (before). THDOC $(20 \mathrm{mg} / \mathrm{kg})$ and finasteride $(50 \mathrm{mg} /$ $\mathrm{kg}$ ) were dissolved in $1 \mathrm{ml}$ of cremaphor heated to $65^{\circ}$ and then $4 \mathrm{ml}$ of $0.9 \%$ injection saline was added. Mice either received vehicle ( $1 \mathrm{ml}$ of cremaphor $+4 \mathrm{ml}$ injection of saline), THDOC, or finasteride $30 \mathrm{~min}$ before a single 30 min restraint stress. The mice were allowed to recover for $30 \mathrm{~min}$ then decapitated and trunk blood was collected (after). Plasma was isolated by high speed centrifugation and corticosterone levels were measured by enzyme immunoassay according to manufacturer's specifications (Enzo Life Sciences). Briefly, duplicate $5 \mu \mathrm{l}$ plasma samples were assayed and absorbance measurements at $415 \mathrm{~nm}$ were compared with a standard curve. Samples from different experimental groups were run in parallel.

\section{Behavioral tests}

Elevated plus maze. Mice were tested for $10 \mathrm{~min}$ on an elevated plus maze, consisting of two open arms $(38 \mathrm{~cm} \times 5 \mathrm{~cm})$ and two closed arms $(38$ $\mathrm{cm} \times 5 \mathrm{~cm} \times 15 \mathrm{~cm})$ with a central open intersection $(5 \mathrm{~cm} \times 5 \mathrm{~cm})$ elevated $75 \mathrm{~cm}$ above the ground. Movement through the maze was detected by 48 equally spaced photocells (Hamilton-Kinder). At the beginning of the test, each mouse was placed individually into the central platform facing an open arm. The time spent and the entries into the open and closed arms were measured by beam breaks using Motor Monitor software (Hamilton-Kinder, Poway, CA). Control, no stress mice were minimally handled before testing. Stress animals were subjected to a single $30 \mathrm{~min}$ restraint stress immediately before testing. THDOC (20 $\mathrm{mg} / \mathrm{kg}$ ) was administered $30 \mathrm{~min}$ before restraint and finasteride (50 $\mathrm{mg} / \mathrm{kg}$ ) was administered $120 \mathrm{~min}$ before restraint.

Open field. Mice were tested for $10 \mathrm{~min}$ in a $40 \mathrm{~cm} \times 40 \mathrm{~cm}$ open field photobeam frame with $16 \times 16$ equally spaced photocells (HamiltonKinder). Mice were placed individually into the center of the open field. The time spent in the center of the open field and the total number of beam breaks were measured using Motor Monitor software (HamiltonKinder). Experimental groups and drug treatments were identical to the elevated plus maze.

\section{Statistical analyses}

All statistical tests were performed using GraphPad Prism 5 software. For the Western blot and immunohistochemistry experiments, statistical significance was determined using a one-way ANOVA with Bonferroni correction for multiple comparisons. Paired electrophysiological 
a

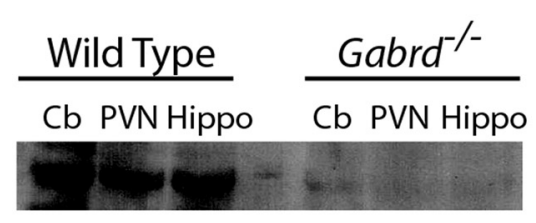

b

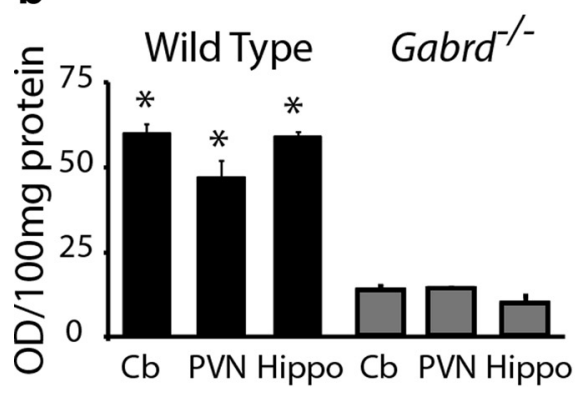

C

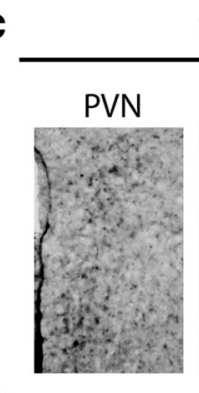

d

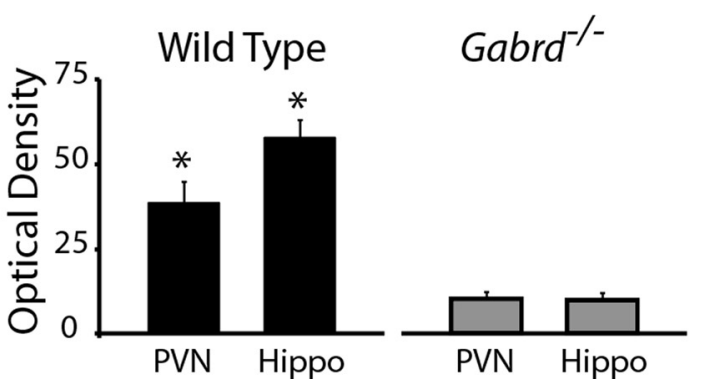

Figure 2. $G_{A B A} R \delta$ subunit expression in the PVN. $\boldsymbol{a}, A$ representative Western blot demonstrating the relative abundance of the $G A B A_{A} R \delta$ subunit in the total protein isolated from the cerebellum, PVN, and hippocampus in wild-type and Gabrd ${ }^{-\prime-}$ mice. $\boldsymbol{b}$, The average optical density of $\mathrm{GABA}_{\mathrm{A}} \mathrm{R} \delta$ subunit expression in the cerebellum, PVN, and hippocampus from wild-type and Gabrd $^{-1-}$ mice. $\boldsymbol{c}$, Representative gray scale images of $G_{A B A} R \delta$ subunit immunoreactivity in the wild-type PVN and hippocampus compared with the Gabrd ${ }^{-1-}$ PVN. $\boldsymbol{d}$, The average optical density of $\mathrm{GABA}_{\mathrm{A}} \mathrm{R} \delta$ subunit demonstrates expression in the PVN and hippocampus in sections from wild-type mice, but not Gabrd ${ }^{-/-}$mice. $n=3$ mice per experimental group; statistical significance of ${ }^{*} p<0.05$ compared with Gabrd $^{-/-}$levels using a one-way ANOVA with Bonferroni correction for multiple comparisons.

a

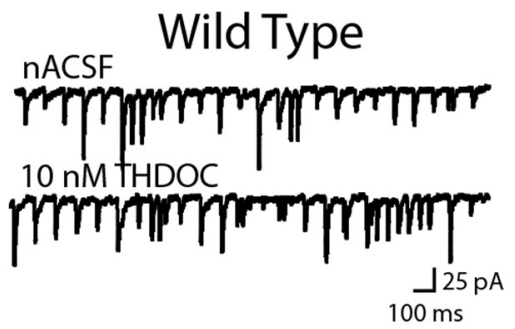

b

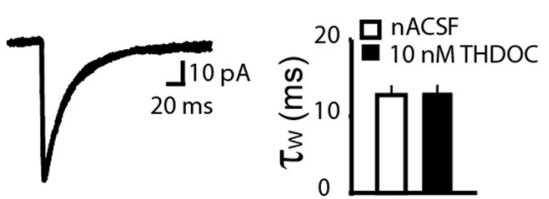

C

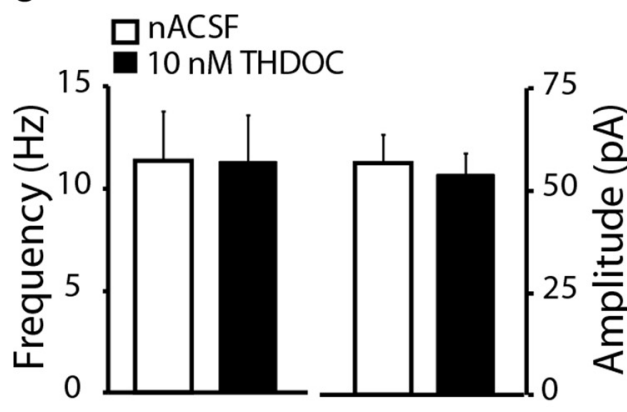

d
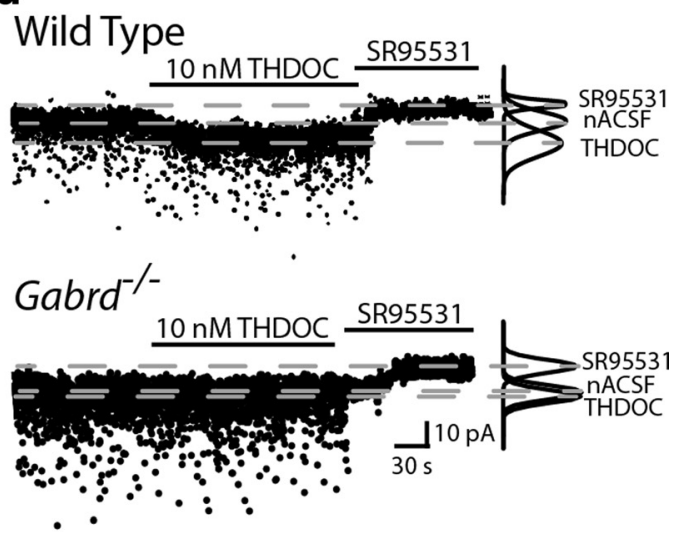

e

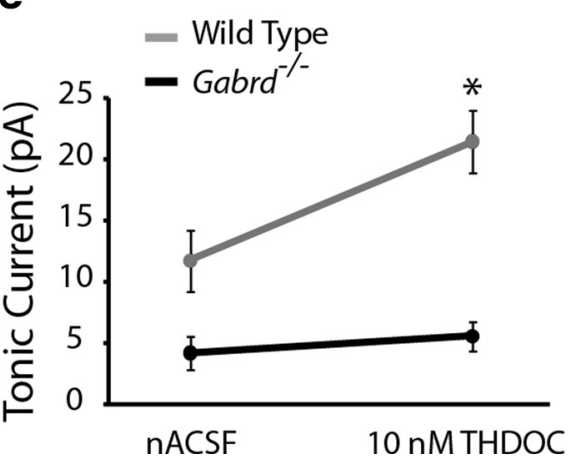

Figure 3. Neurosteroid regulation of CRH neurons. $\boldsymbol{a}$, Representative traces of sIPSCs from GFP-positive CRH neurons in the presence or absence of $10 \mathrm{~nm}$ THDOC. $\boldsymbol{b}$, The superimposed average SIPSCs in the presence or absence of $10 \mathrm{~nm}$ THDOC highlight that there is no effect of THDOC on the average decay time $\left(\tau_{\mathrm{w}}\right)$ (see inset). $c$, The average histograms demonstrate that THDOC did not significantly alter the frequency or amplitude of sIPSCs. $\boldsymbol{d}$, Representative traces of the tonic current in CRH-GFP neurons from wild-type and Gabrd ${ }^{-1-}$ mice held at $-70 \mathrm{mV}$ throughout the addition of $10 \mathrm{~nm}$ THDOC and saturating concentrations of SR95531. , The average tonic current is significantly decreased in CRH neurons from Gabrd ${ }^{-1-}$ mice compared with wild-type. THDOC (10 nм) enhanced the tonic GABAergic inhibition in CRH-GFP neurons from wild-type mice, but not Gabrd ${ }^{-1-}$ mice. $n=6-12$ mice, $15-32$ cells; statistical significance of ${ }^{*} p<0.05$ using a paired $t$ test. 
Table 2. Electrophysiological properties of CRH-GFP neurons in wild-type and Gabrd $^{-1-}$ mice under stress and THDOC conditions

\begin{tabular}{|c|c|c|c|c|c|}
\hline & $\begin{array}{l}\text { sIPSC frequency } \\
(\mathrm{Hz})\end{array}$ & $\begin{array}{l}\text { sIPSC Peak } \\
\text { Amplitude } \\
(\mathrm{pA})\end{array}$ & $\mathrm{sIPSC} \mathrm{t}_{\mathrm{w}}$ (ms) & $\begin{array}{l}\text { Tonic current } \\
\text { (pA) }\end{array}$ & $\begin{array}{l}\text { Firing Rate } \\
(\mathrm{Hz})\end{array}$ \\
\hline Wild-type nACSF & $11.4 \pm 2.4$ & $56.9 \pm 6.8$ & $12.8 \pm 1.2$ & $11.2 \pm 2.5$ & $5.5 \pm 1.0$ \\
\hline Wild-type THDOC & $11.3 \pm 2.3$ & $54.0 \pm 5.2$ & $13.0 \pm 1.0$ & $20.9 \pm 2.5^{*}$ & $2.8 \pm 0.6^{*}$ \\
\hline Gabrd $^{-1-}$ nACSF & & & & $3.1 \pm 1.4$ & $8.4 \pm 0.8$ \\
\hline $\mathrm{Gabr}^{-1-}$ THDOC & & & & $4.5 \pm 1.2$ & $9.8 \pm 1.4$ \\
\hline
\end{tabular}

* denotes significance compared to wild-type nACSF.

Table 3. Electrophysiological properties (perforated patch firing rate) of CRH-GFP neurons in wild-type and $\mathrm{Gabrd}^{-1-}$ mice under stress and THDOC conditions

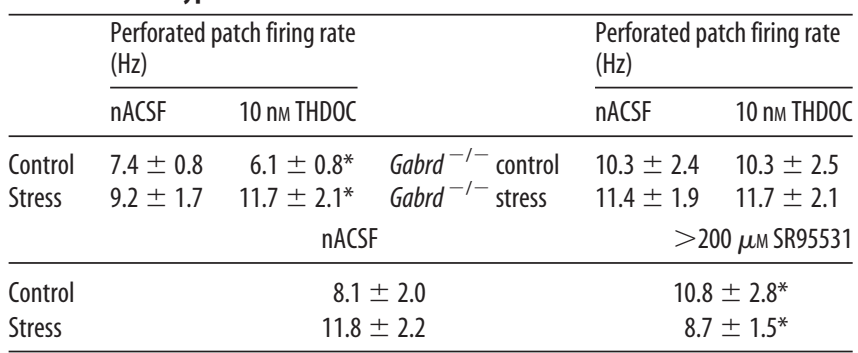

* denotes significance compared to $\mathrm{nACSF}$ a
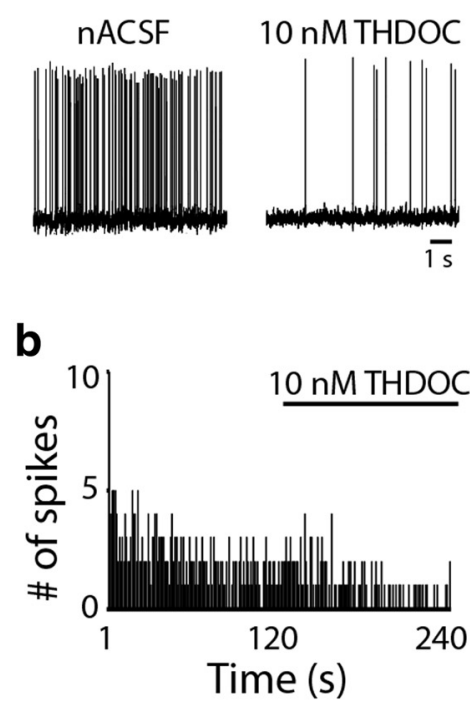

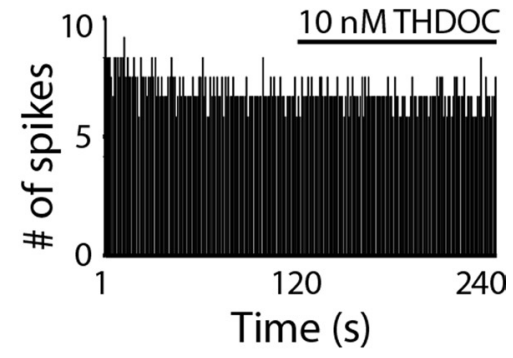

C

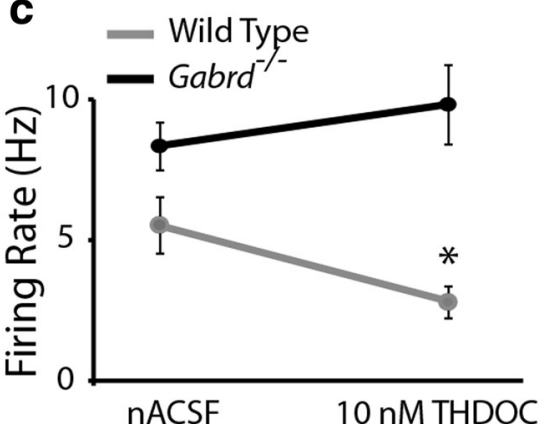

experiments investigating the effect of THDOC or SR95531 in both wildtype and $\mathrm{Gabrd}^{-1-}$ mice were analyzed using a paired $t$ test. Similarly, the paired corticosterone measurements were also analyzed using a paired $t$ test. A significant correlation between the level of KCC2 residue Ser940 phosphorylation and corticosterone levels was determined using the Spearman rank order correlation. A one-way ANOVA with a Bonferroni post hoc test was used to determine statistical significance for all the behavioral experiments.

\section{Results}

$\mathrm{GABA}_{\mathrm{A}} \mathbf{R} \boldsymbol{\delta}$ subunit expression in the PVN

We compared the expression of the $\mathrm{GABA}_{\mathrm{A}} \mathrm{R} \delta$ subunit in the $\mathrm{PVN}$ with that in the hippocampus and cerebellum, brain regions known to be enriched in this subunit. Western blot analysis of total protein isolated from these three regions showed comparable relative abundance of this subunit (PVN: $48.2 \pm 3.8$, hippocampus: $57.7 \pm 1.5$, cerebellum: $59.0 \pm 2.0 \mathrm{OD}$ units $/ 100 \mu \mathrm{g}$ total protein) (Fig. $2 a, b$ ). Total protein isolated from $\mathrm{GABA}_{\mathrm{A}} \mathrm{R} \delta$ subunit knock-out mice (Gabrd ${ }^{-/-}$mice) run on the same gel with equivalent amounts of protein exhibited negligible $\mathrm{GABA}_{\mathrm{A}} \mathrm{R}$ $\delta$ subunit expression (PVN: $13.7 \pm 0.3$, hippocampus: $9.6 \pm 2.0$, cerebellum: $13.6 \pm 1.1 \mathrm{OD}$ units/100 $\mu \mathrm{g}$ total protein; Fig. $2 a, b$ ) ( $n=3-8$ mice per group; statistical significance of $p<0.05$ determined using a one-way ANOVA with a Bonferroni correction for multiple comparisons: $F=43.41$; df within-group $=23$; df between group $=5$ ), demonstrating the specificity of the $\mathrm{GABA}_{\mathrm{A}} \mathrm{R} \delta$ subunit expression by Western blot analysis. $\mathrm{GABA}_{\mathrm{A}} \mathrm{R} \delta$ subunit expression in the PVN was also analyzed using immunohistochemistry. The PVN was labeled by intraperitoneal injection of fluorogold (200 $\mu \mathrm{l}$ of $10 \%$ fluorogold) and the expression of the $\mathrm{GABA}_{\mathrm{A}} \mathrm{R} \delta$ subunit in the fluorogoldlabeled region of interest (PVN) was compared between wild-type and $G a$ $\mathrm{brd}^{-1-}$ mice. The immunohistochemistry results confirmed the Western blot data demonstrating that immunoreactivity for the $\mathrm{GABA}_{\mathrm{A}} \mathrm{R} \delta$ subunit in the PVN (38.5 \pm 6.5 OD units) was comparable to the dentate gyrus (57.7 $\pm 5.4 \mathrm{OD}$ units). However, the $\mathrm{GABA}_{\mathrm{A}} \mathrm{R} \delta$ subunit was not expressed in Gabrd $^{-/-}$mice (PVN: $10.1 \pm 2.2$, dentate gyrus: $9.9 \pm 2.2$ OD units) (Fig. $2 c, d)(n=3$ animals per experimental group; statistical significance of $p<0.05$ determined using a one-way ANOVA with Bonferroni correction for multiple comparisons: $F=16.82$; df within-group $=43$; df between group $=3$ ). These data demonstrate that the $\mathrm{GABA}_{\mathrm{A}} \mathrm{R} \delta$ subunit may be functionally relevant in CRH neurons.

\section{Neurosteroid regulation of CRH neurons}

To determine whether $\mathrm{CRH}$ neurons are regulated by neurosteroid-sensitive $\mathrm{GABA}_{\mathrm{A}} \mathrm{R} \delta$ subunit-containing receptors, we performed whole-cell patch-clamp recordings on visually identified CRH neurons (see Materials and Methods). Spontaneous IPSCs (sIPSCs) were recorded in the same neurons in the presence or absence of the
Figure 4. Neurosteroid regulation of CRH neuronal activity. $\boldsymbol{a}$, Representative traces of the spontaneous firing rate of CRH-GFP neurons from wild-type and Gabrd ${ }^{-1-}$ mice in NACSF and $10 \mathrm{nM}$ THDOC. $\boldsymbol{b}$, The binned firing rate $(1 \mathrm{~s}$ bins) in the same representative CRH neuron over time in the presence of nACSF or $10 \mathrm{nM}$ THDOC (where indicated) from a wild-type (left) and Gabrd $^{-1-}$ mouse (right). c, THDOC significantly decreased the basal firing rate of CRH-GFP neurons from wild-type mice, but not Gabrd $^{-1-}$ mice. $n=12-13$ cells, 6 mice per experimental group; significance of ${ }^{*} p<0.05$ compared with firing rate in nACSF using a paired $t$ test. 
stress-derived neurosteroid, THDOC (10 $\mathrm{nM})$, a concentration acting preferentially at extrasynaptic $\mathrm{GABA}_{\mathrm{A}}$ Rs (Stell et al., 2003). We did not observe any differences in the frequency (nACSF: $11.4 \pm 2.4$, THDOC: $11.3 \pm 2.3 \mathrm{~Hz}$ ), amplitude (nACSF: $56.9 \pm$ 6.8, THDOC: $54.0 \pm 5.2 \mathrm{pA}$ ), or weighted decay $\left(\tau_{\mathrm{w}}\right)$ (nACSF: $12.8 \pm 1.2$, THDOC: $13.0 \pm 1.0 \mathrm{~ms})$ of sIPSCs in the presence of 10 nM THDOC (Fig. $3 a-c$, Table 2$)(n=19$ cells, 8 mice per experimental group; statistical significance $p<0.05$ using a paired $t$ test). However, we did observe a significant potentiation of the tonic GABAergic current in the presence of $10 \mathrm{nM}$ THDOC (20.9 \pm $2.5 \mathrm{pA})$ compared with nACSF $(11.2 \pm 2.5$ pA) (Fig. 3d,e, Table 2) ( $n=32$ cells, 12 mice per experimental group; statistical significance $p<0.05$ using a paired $t$ test). These data demonstrate the presence of a neurosteroid-sensitive tonic GABAergic current in CRH neurons, consistent with the expression of the $\mathrm{GABA}_{\mathrm{A}} \mathrm{R} \delta$ subunit (Fig. 2).

Consistent with a role of the $\mathrm{GABA}_{\mathrm{A}} \mathrm{R}$ $\delta$ subunit in the regulation of CRH neurons, the tonic current in CRH neurons from Gabrd $^{-/-}$mice was significantly decreased $(3.1 \pm 1.4 \mathrm{pA})$ compared with wild-type levels (11.2 $\pm 2.5 \mathrm{pA})$. Further, CRH neurons from $\mathrm{Gabrd}^{-1-}$ mice did not exhibit a neurosteroid-sensitive tonic GABAergic current (nACSF: $3.1 \pm 1.4$, THDOC: $4.5 \pm 1.2 \mathrm{pA}$ ) (Fig. $3 d$,e, Tables $2,3)(n=15-32$ cells, $6-12$ mice per experimental group; statistical significance of $p>0.05$ using a paired $t$ test). These data implicate the $\mathrm{GABA}_{\mathrm{A}} \mathrm{R} \delta$ subunit in the neurosteroid-regulation of CRH neurons.

To determine the impact of neurosteroid modulation of $\mathrm{GABA}_{\mathrm{A}}$ Rs on the activity of $\mathrm{CRH}$ neurons, we performed current-clamp recordings on visually identified CRH neurons. The spontaneous firing rate of $\mathrm{CRH}$ neurons from wild-type mice was significantly reduced in the presence of $10 \mathrm{~nm}$ THDOC $(2.8 \pm 0.6 \mathrm{~Hz})$ compared with nACSF $(5.5 \pm 1.0 \mathrm{~Hz})$ (Fig. 4 , Table 2$)(n=12$ cells, 6 mice per experimental group; statistical significance $p<0.05$ using a paired $t$ test). Consistent with the role of the $\mathrm{GABA}_{\mathrm{A}} \mathrm{R}$ $\delta$ subunit in mediating the neurosteroid-sensitivity of $\mathrm{CRH}$ neurons, THDOC did not significantly alter the spontaneous firing rate of CRH neurons from Gabrd ${ }^{-1-}$ mice (Fig. 4, Table 2) (nACSF: $8.4 \pm 0.8 \mathrm{~Hz}$; THDOC: $9.8 \pm 1.4 \mathrm{~Hz})(n=12-13$ cells, 6 mice per experimental group; significance $p>0.05$ using a paired $t$ test). These data demonstrate a role for the $\mathrm{GABA}_{\mathrm{A}} \mathrm{R} \delta$ subunit in the regulation of $\mathrm{CRH}$ neurons via conferring neurosteroid sensitivity.

\section{Neurosteroid actions on CRH neurons regulate corticosterone levels}

To investigate whether neurosteroid modulation of $\mathrm{CRH}$ neurons constitutes a novel regulatory mechanism on HPA axis activity, we
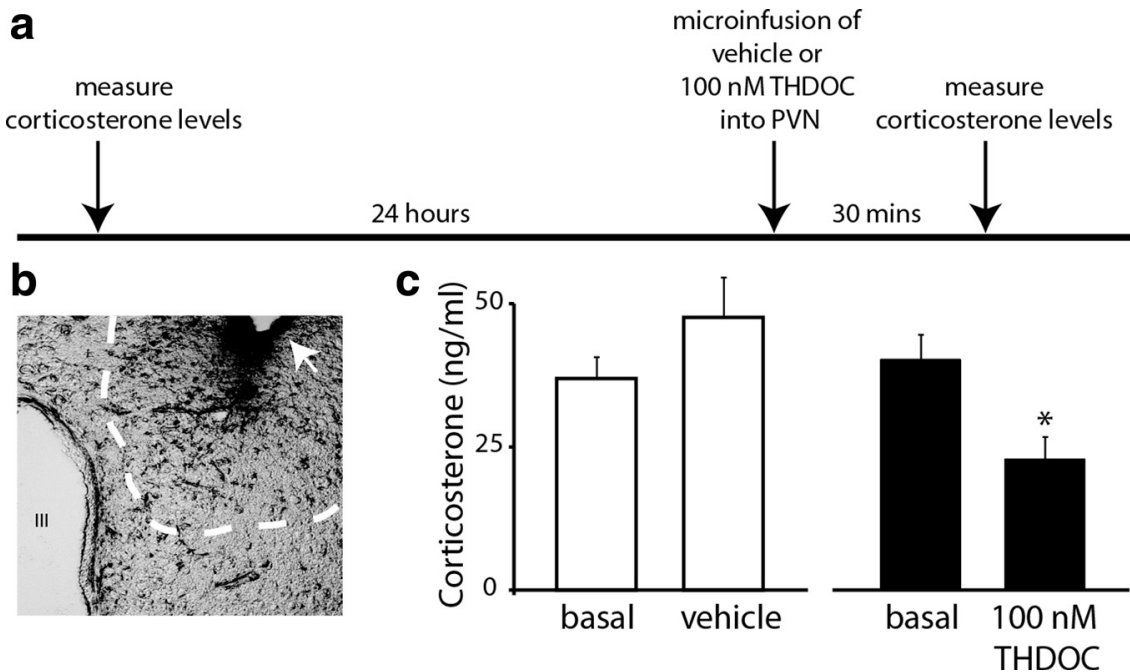

Figure 5. Local administration of THDOC into the PVN is sufficient to alter HPA axis activity. $\boldsymbol{a}$, Timeline of blood sample collection, microinfusion, and corticosterone measurements. $\boldsymbol{b}$, A representative section demonstrating cresyl violet diffusion into the PVN of wild-type mice following microinfusion of $100 \mathrm{~nm}$ THDOC. Dotted line represents the extent of cresyl violet staining from vels within $30 \mathrm{~min}$. Vehicle administration did not alter corticosterone levels. $n=6$ mice per experimental group; significance of $p<0.05$ compared with basal corticosterone levels using a paired $t$ test.

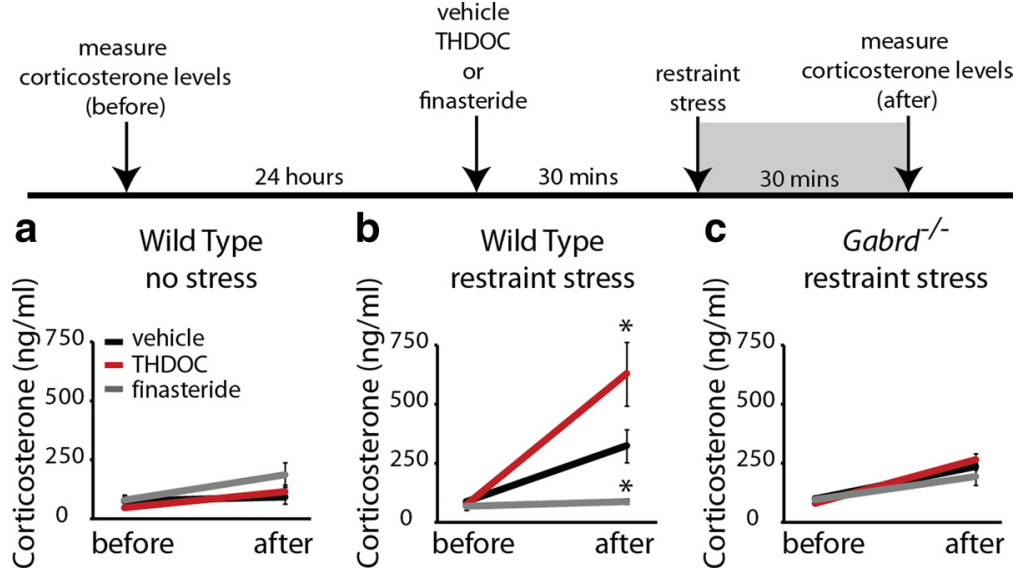

Figure 6. Neurosteroids exacerbate the corticosterone response to stress. $\boldsymbol{a}$, Average corticosterone levels in paired samples measured efore and after treatment with vehicle, THDOC ( $20 \mathrm{mg} / \mathrm{kg}$ ) and finasteride $(50 \mathrm{mg} / \mathrm{kg})$. $\boldsymbol{b}$, The average corticosterone levels in paired

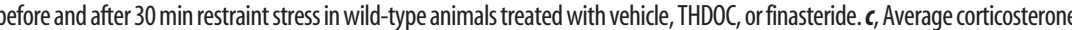
evels measured before and after 30 min restraint stress in vehicle, THDOC, and finasteride-treated Gabrd ${ }^{-1-}$ mice. $n=5-11$ mice per experimental group; significance of ${ }^{*} p<0.05$ using a one-way ANOVA with Bonferroni correction for multiple comparisons.

analyzed the effect of THDOC microinfusion directly into the PVN on circulating corticosterone levels. Corticosterone levels were measured $24 \mathrm{~h}$ before and $30 \mathrm{~min}$ after microinfusion with either THDOC $(0.5 \mu \mathrm{l}, 100 \mathrm{~nm}$ in $0.5 \%$ cresyl violet $)$ or vehicle $(0.5 \mu \mathrm{l}$, $0.5 \%$ cresyl violet) (Fig. $5 a$ ). Cresyl violet staining was used to ensure the location and the extent of the microinfusion into the PVN (Fig. 5b). Vehicle administration into the PVN did not significantly affect circulating corticosterone levels (pre: $37.1 \pm 3.7 \mathrm{ng} / \mathrm{ml}$; post-vehicle: $53.6 \pm 8.1 \mathrm{ng} / \mathrm{ml}$ ). Local administration of THDOC into the PVN was sufficient to decrease circulating levels of corticosterone within $30 \mathrm{~min}$ (pre: $40.3 \pm 4.4 \mathrm{ng} / \mathrm{ml}$; post-THDOC: $26.9 \pm 4.9 \mathrm{ng} / \mathrm{ml}$; Fig. $5 c$ ) ( $n=6$ mice per experimental group; significance $p<0.05$ using a paired $t$ test). These data demonstrate that neurosteroids act locally in the PVN to decrease the activity of the HPA axis under basal conditions. 
a

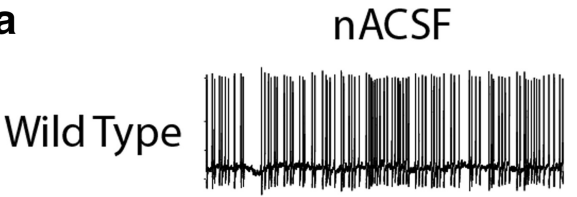

stress

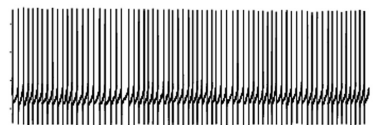

$\mathrm{Gabrd}^{-/-}$
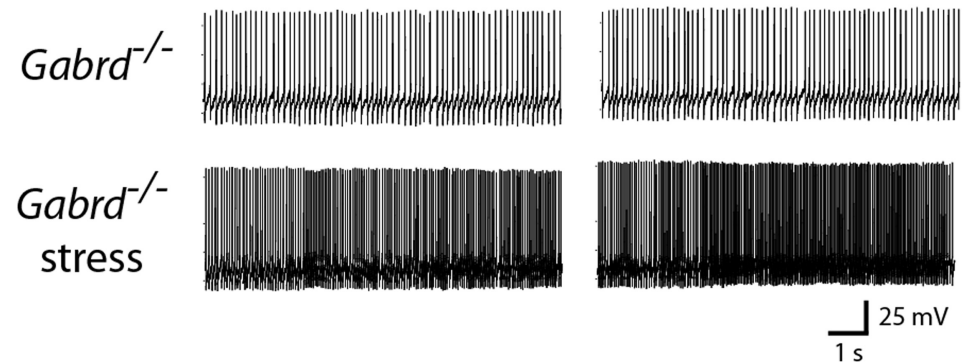

b
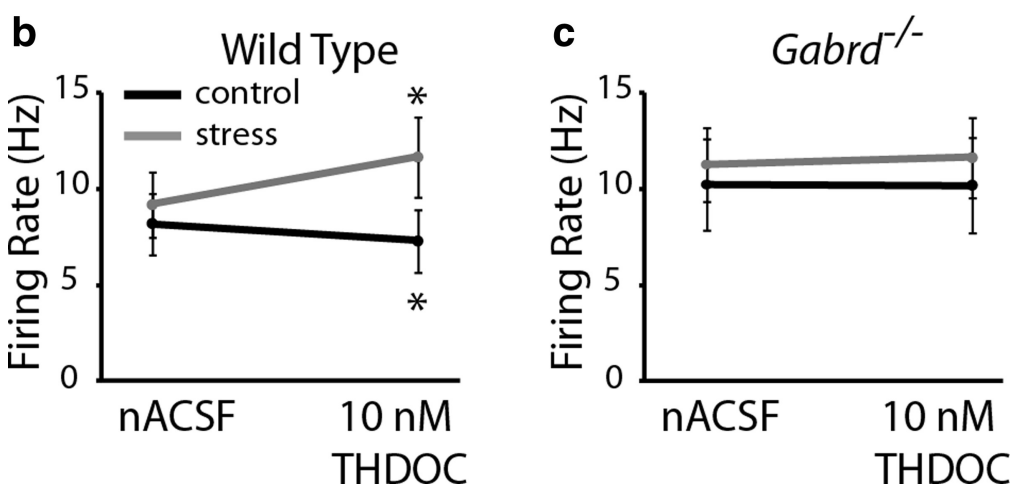

Figure 7. THDOC increases the activity of CRH neurons following stress. $\boldsymbol{a}$, Representative traces of the basal firing rate of CRH-GFP neurons recorded under perforated patch, current clamp $/=0$ conditions from wild-type and Gabrd ${ }^{-1-}$ mice in nACSF and $10 \mathrm{~nm}$ THDOC. $\boldsymbol{b}$, The average firing rate in paired samples in the presence or absence of THDOC in control wild-type mice or mice subjected to $30 \mathrm{~min}$ restraint stress. $c$, The average firing rate of CRH neurons in control or stress $\mathrm{Gabrd}^{-1-}$ mice in the presence or absence of THDOC. $n=$ 11-12 cells, $5-6$ mice per experimental group; significance of ${ }^{*} p<0.05$ compared with the firing rate in $\mathrm{nACSF}$ using a paired $t$ test.

corticosterone response to stress $(71.1 \pm$ $11.0 \mathrm{ng} / \mathrm{ml})$ compared with vehicle $(306.7 \pm 69.8 \mathrm{ng} / \mathrm{ml})$ (Fig. $6 b)(n=5-11$ mice per experimental group; statistical significance, $p<0.05$ using a one-way ANOVA with Bonferroni post hoc test: $F=$ 12.98; df within-group $=30$; $\mathrm{df}$ between group $=5$ ). There was no significant difference in the basal levels measured $24 \mathrm{~h}$ prior (vehicle: $72.1 \pm 6.2 \mathrm{ng} / \mathrm{ml}$; THDOC: $56.4 \pm$ $7.0 \mathrm{ng} / \mathrm{ml}$; finasteride: $51.8 \pm 16.1 \mathrm{ng} / \mathrm{ml}$ ). In $\mathrm{Gabrd}^{-/-}$mice, there was no significant difference in the corticosterone levels following stress in vehicle $(185.4 \pm 15.7 \mathrm{ng} /$ $\mathrm{ml})$, THDOC $(211.8 \pm 28.2 \mathrm{ng} / \mathrm{ml})$, or finasteride $(142.2 \pm 35.9 \mathrm{ng} / \mathrm{ml})$-treated animals. Similarly, there was no difference in their prestress levels (Fig. 6c) (vehicle: $46.3 \pm 14.5 \mathrm{ng} / \mathrm{ml}$; THDOC: $29.7 \pm 5.4 \mathrm{ng} /$ $\mathrm{ml}$; finasteride: $46.0 \pm 14.9 \mathrm{ng} / \mathrm{ml})(n=7-9$ mice per experimental group; no statistical difference determined using a one-way ANOVA with Bonferroni post hoc test: $F=$ 13.69; $\mathrm{df}$ within-group $=46$; $\mathrm{df}$ between group $=5$ ). These data demonstrate that neurosteroidogenesis and $\mathrm{GABA}_{\mathrm{A}} \mathrm{R} \delta$ subunit-containing receptors play a critical role in HPA axis reactivity in response to stress.

\section{Neurosteroids increase the activity of $\mathrm{CRH}$ neurons following stress}

The evidence that THDOC increased corticosterone levels in response to stress lead us to hypothesize that THDOC may increase the activity of CRH neurons following stress rather than inhibit their activity. To investigate this hypothesis, we measured the spontaneous firing rate of $\mathrm{CRH}$ neurons in the perforated patch $I=0$

\section{Neurosteroidogenesis mediates}

stress-induced elevations in corticosterone levels

To further investigate the role of neurosteroid modulation of $\mathrm{CRH}$ neurons on HPA axis reactivity, we examined the effect of THDOC and an inhibitor of neurosteroidogenesis, finasteride, on circulating corticosterone levels. The effect of neurosteroids on corticosterone release under no-stress conditions was analyzed by comparing the corticosterone levels in mice treated with vehicle, THDOC (20 mg/ $\mathrm{kg}$, i.p.), or finasteride $(50 \mathrm{mg} / \mathrm{kg}$, i.p.) with basal levels in these mice measured $24 \mathrm{~h}$ before. Our data suggest that under basal conditions, there was no significant difference in the effect of vehicle $(92.1 \pm 28.9$ $\mathrm{ng} / \mathrm{ml})$, THDOC $(116.6 \pm 27.8 \mathrm{ng} / \mathrm{ml})$ or finasteride $(186.3 \pm 52.0$ $\mathrm{ng} / \mathrm{ml}$ ) on corticosterone levels compared with the basal levels measured $24 \mathrm{~h}$ prior (vehicle: $77.7 \pm 19.1 \mathrm{ng} / \mathrm{ml}$; THDOC: $46.9 \pm 5.5$ $\mathrm{ng} / \mathrm{ml}$; finasteride: $81.5 \pm 21.9 \mathrm{ng} / \mathrm{ml})$ (Fig. $6 a)(n=5-11$ mice per experimental group; $p>0.05$ determined using a one-way ANOVA with Bonferroni post hoc test: $F=2.381$; df within-group $=42$; df between group $=5$ ). We used the restraint stress paradigm to investigate the role of neurosteroid modulation of the HPA axis on stress reactivity. Interestingly, mice treated with THDOC $30 \mathrm{~min}$ before restraint stress exhibited a significant increase in corticosterone levels $(611.4 \pm 135.4 \mathrm{ng} / \mathrm{ml})$ compared with vehicle $(306.7 \pm 69.8$ $\mathrm{ng} / \mathrm{ml}$ ). In contrast, finasteride treatment completely blocked the current-clamp mode. Our data demonstrate that under basal conditions, THDOC (10 nM) decreased the spontaneous firing rate of CRH neurons (nACSF: $7.4 \pm 0.8$, THDOC: $6.1 \pm 0.8 \mathrm{~Hz}$ ) (Fig. $7 a, b$, Table 3). In contrast, following restraint stress, THDOC significantly increased the firing rate of CRH neurons (nACSF: $9.2 \pm 1.7$, THDOC: $11.7 \pm 2.1 \mathrm{~Hz}$ ) (Fig. $7 a, b$, Table 3) $(n=11-13$ cells, $5-6$ mice per experimental group; significance $p<0.05$ using a paired $t$ test). In Gabrd ${ }^{-1-}$ mice under basal conditions, there is no difference in the firing rate of $\mathrm{CRH}$ neurons in the presence of $10 \mathrm{nM}$ THDOC (nACSF: $10.3 \pm 2.4$, THDOC: $10.3 \pm 2.5 \mathrm{~Hz}$ ) (Fig. 7a,c, Table 3). Similarly, in Ga$\mathrm{brd}^{-1-}$ mice subjected to restraint stress, THDOC has no effect on the firing rate of CRH neurons (nACSF: $11.4 \pm 1.9$, THDOC: $11.7 \pm 2.1 \mathrm{~Hz})$ (Fig. $7 a, c$, Table 3$)(n=11-12$ cells, $5-6$ mice per experimental group; $p>0.05$ determined using a paired $t$ test). These data suggest that following stress THDOC increases the activity of $\mathrm{CRH}$ neurons via actions on $\mathrm{GABA}_{\mathrm{A}} \mathrm{R} \delta$ subunitcontaining receptors.

To determine whether THDOC increases the activity of $\mathrm{CRH}$ neurons following stress via excitatory actions of GABA, we determined whether spontaneous IPSPs (sIPSPs) were hyperpolarizing or depolarizing following stress using gramicidin perforated patch-clamp recordings. Our data demonstrate that under basal 
conditions, $100 \pm 0.0 \%$ of cells exhibited hyperpolarizing sIPSPs consistent with the inhibitory actions of GABA. In contrast, following stress only $16.7 \pm 11.2 \%$ of slices exhibited hyperpolarizing sIPSPs; whereas, $83.3 \pm 11.2 \%$ of cells exhibited depolarizing sIPSPs (Fig. $8 a, b)(n=10-12$ cells, 4 mice per experimental group; significance $p<$ 0.05 determined using an unpaired $t$ test). These data suggest that the actions of GABA are largely excitatory in CRH neurons following stress. To confirm these findings, we analyzed the effect of the GABA antagonist, SR95531, on the spontaneous firing rate of CRH neurons under perforated patch $I=0$ conditions. Our data demonstrate that under basal conditions, SR95531 (>200 $\mu \mathrm{M})$ increased the spontaneous firing rate of CRH neurons (nACSF: $8.1 \pm 2.0$, SR95531: $10.8 \pm 2.8 \mathrm{~Hz}$ ) (Fig. $8 c, d$, Table 3). In contrast, following restraint stress, SR95531 significantly decreased the firing rate of $\mathrm{CRH}$ neurons (nACSF: $11.8 \pm 2.2$, SR95531: $8.7 \pm 1.5 \mathrm{~Hz})$ (Fig. $8 c, d$, Table 3$)(n=12$ cells, 4 mice per experimental group; significance $p<0.05$ determined using a paired $t$ test). These results demonstrate that GABA switched from inhibitory to excitatory following stress.

\section{Decreased phosphorylation of KCC2 residue Ser940 in the PVN following stress}

The evidence that THDOC increases the excitability of $\mathrm{CRH}$ neurons following stress suggests a collapse in the chloride gradient as previously reported (Hewitt et al., 2009). To investigate whether the collapse in the chloride gradient is due to a loss in KCC2, we analyzed the expression of KCC2 in total protein isolated from the microdissected PVN in control mice and mice subjected to restraint stress. Our data demonstrate a modest, yet statistically significant, decrease in total KCC2 levels in the PVN following stress (92.4 \pm 3.8 OD units $/ 50 \mu \mathrm{g}$ protein) compared with control (104.9 \pm 3.4 OD units/50 $\mu \mathrm{g}$ protein) (Fig. $9 a, b)$ ( $n=8$ mice per experimental group; significance $p<0.05$ determined using an unpaired $t$ test). Dephosphorylation of KCC2 residue Ser940 has been shown to decrease its cell surface expression and activity (Lee et al., 2010). Using a phospho-specific antibody to KCC2 Ser940, we demonstrate a significant decrease in the phosphorylation of KCC2 residue Ser940 following stress $(38.4 \pm 8.7$ OD units $/ 50 \mu \mathrm{g}$ protein) compared with control (67.1 \pm 10.1 OD units $/ 50 \mu$ g protein) (Fig. $9 a, c)(n=8$ mice per experimental group; significance $p<0.05$ determined using an unpaired $t$ test). Furthermore, the percentage of phosphorylated KCC2 was significantly decreased following stress (40.4 $\pm 8.0 \%)$ using a paired $t$ test.

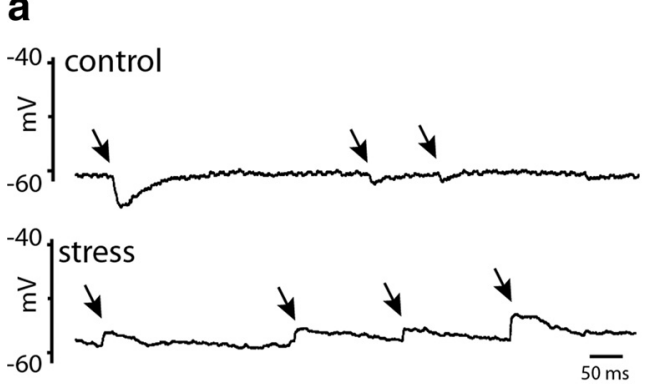

b
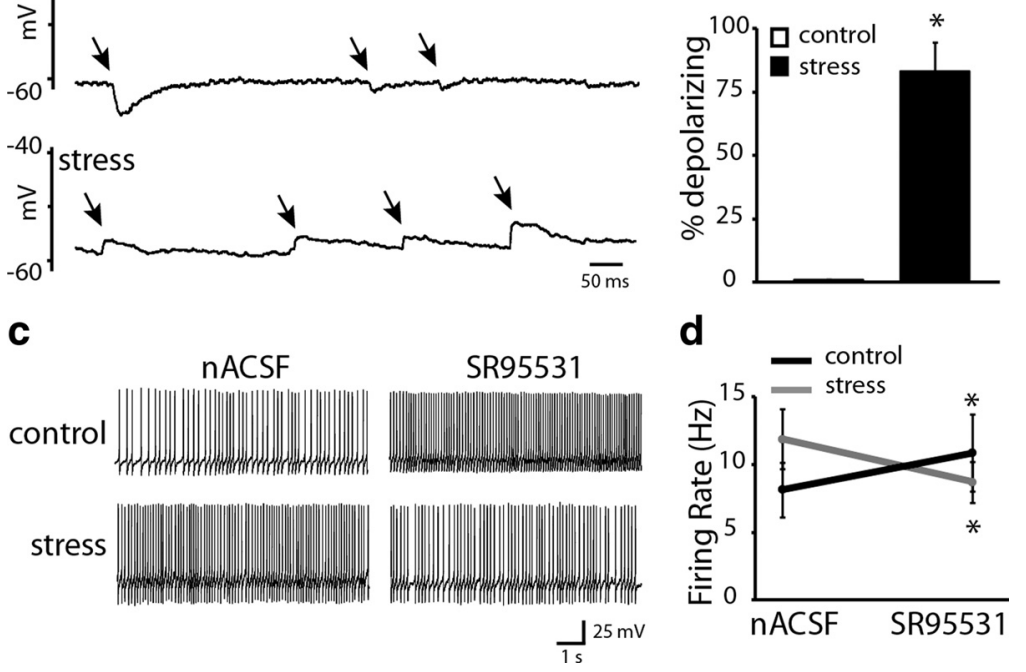

Figure 8. Depolarizing and excitatory GABAergic responses following stress. $\boldsymbol{a}$, Representative, hyperpolarizing sIPSPs recorded in CRH-GFP neurons under perforated patch, current clamp / = 0 conditions from control wild-type mice and depolarizing sIPSPs recorded in slices from mice subjected to acute restraint stress. $\boldsymbol{b}$, The percentage of cells exhibiting depolarizing sIPSPs from control and stress wild-type mice. $n=10-12$ cells, 4 mice per experimental group; significance of ${ }^{*} p<0.05$ using an unpaired $t$ test. $c$, Representative traces of the basal firing rate of CRH-GFP-positive neurons recorded under perforated patch, current clamp $I=0$ conditions from control and stress wild-type mice in nACSF and SR95531. $\boldsymbol{d}$, The average firing rate of CRH neurons from control or stress mice in the presence or absence of SR95531. $n=12$ cells, 4 mice per experimental group; significance of ${ }^{*} p<0.05$
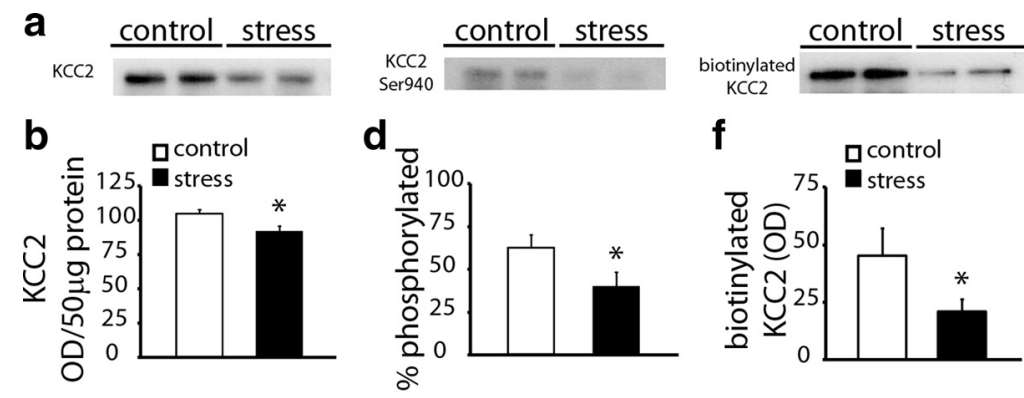

f
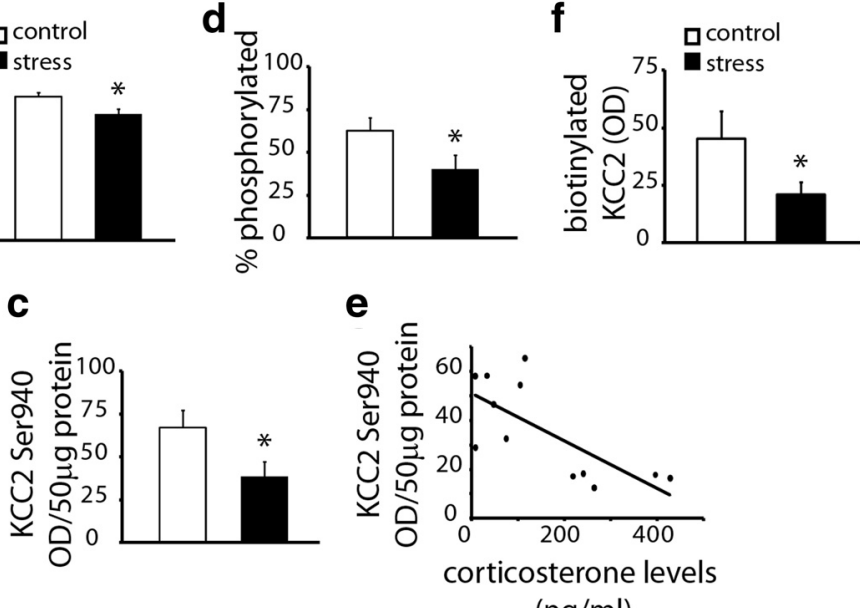

(ng/ml)

Figure 9. Dephosphorylation and downregulation of KCC2 following stress. $\boldsymbol{a}$, Representative Western blot demonstrating decreased expression of KCC2 (left), phosphorylation of KCC2 residue Ser940 (center), and surface biotinylated KCC2 (right) in tw0 independent PVN samples in control and stress mice. $\boldsymbol{b}$, The average optical density measurements of KCC2 expression in control mice and mice subjected to 30 min restraint stress. $c$, The average optical density of phosphorylated KCC2 residue Ser 940 in the PVN from control or stress mice. $\boldsymbol{d}$, The percentage of phosphorylated $\mathrm{KCC} 2$ is significantly decreased following stress compared with control. e, A Spearman rank order correlation of corticosterone levels and phosphorylation levels of KCC2 residue Ser940 reveals a significant negative correlation $(r=-0.6993)$. $\boldsymbol{f}$, The average biotinylated KCC2 expression in the PVN of control and stress wild-type mice. $n=8-10$ mice per experimental group; significance of ${ }^{*} p<0.05$ compared with control using an unpaired $t$ test. compared with control $(62.6 \pm 7.7 \%)$ (Fig. $9 d)(n=8$ mice per experimental group; significance $p<0.05$ determined using an unpaired $t$ test). A regression analysis revealed a significant negative correlation between the levels of phosphorylation of KCC2 residue 


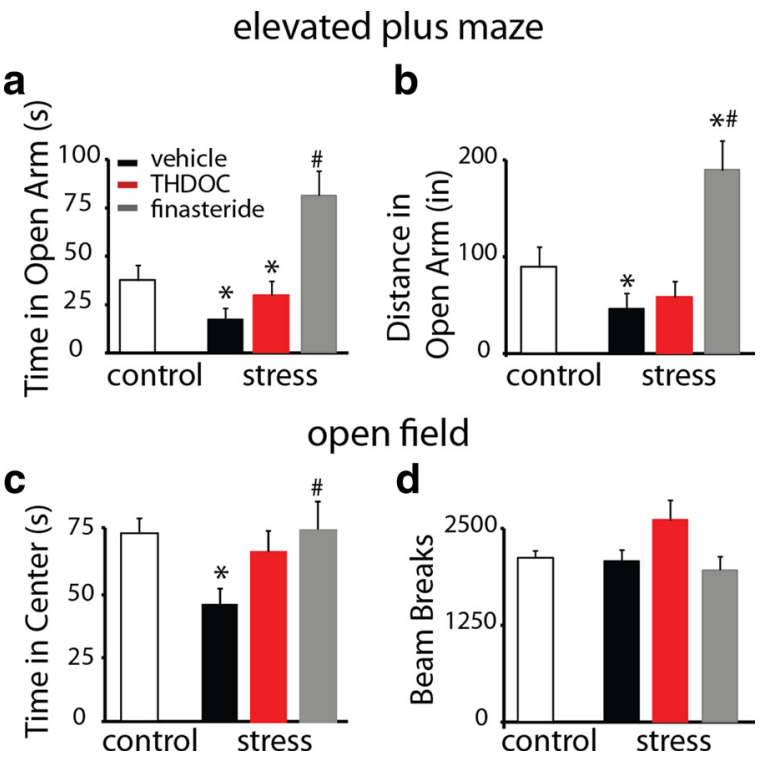

Figure 10. Neurosteroidogenesis is required for stress-induced anxiety-like behavior. $\boldsymbol{a}, \boldsymbol{b}$, The average time spent $(\boldsymbol{a})$ and the distance traveled $(\boldsymbol{b})$ in the open arm of the elevated plus maze in control mice and mice subjected to 30 min restraint stress and treated with vehicle, THDOC, or finasteride. $c$, The average time spent in the center of the open field in control mice and vehicle, THDOC, or finasteride-treated mice subjected to 30 min restraint stress. $\boldsymbol{d}$, The average locomotor behavior, assessed by the number of beam breaks, in control mice and vehicle, THDOC, or finasteride-treated mice subjected to 30 min restraint stress. $n=11-12$ mice per experimental group; ${ }^{*} p<0.05$ compared with control, ${ }^{\#} p<0.05$ compared with vehicle-treated stress using a one-way ANOVA with Bonferroni correction for multiple comparisons.

Ser940 and corticosterone levels $(r=-0.6993)$ (Fig. $9 e)(n=12 ; p=$ 0.0142 determined using a Spearman rank order correlation). To determine whether alterations in KCC2 residue Ser940 phosphorylation had an effect on surface expression of KCC2, we performed a surface biotinylation assay and probed for KCC2. These data demonstrate a decrease in surface biotinylated KCC2 in the PVN following stress $(21.1 \pm 5.3 \mathrm{OD}$ units $/ 50 \mu \mathrm{g}$ protein) compared with control (45.4 \pm 11.9 OD units/50 $\mu$ g protein) (Fig. $9 f)$ ( $n=10$ mice per experimental group; significance $p<0.05$ determined using an unpaired $t$ test). These data indicate that dephosphorylation of KCC2 residue Ser940 plays a key role in HPA axis reactivity to stress.

\section{Neurosteroidogenesis mediates stress-induced anxiety}

Our data demonstrate that blocking neurosteroidogenesis with finasteride is sufficient to block the corticosterone response to stress (Fig. 6b). Therefore, we investigated the effect of neurosteroidogenesis on stress-induced anxiety-like behavior. Following restraint stress, mice spend significantly less time $(16.9 \pm 5.8 \mathrm{~s})$ and travel a shorter distance $(46.5 \pm 16.2 \mathrm{in})$ in the open arm of the elevated plus maze compared with control mice (time: $37.2 \pm$ 7.9 s; distance: $89.5 \pm 20.6$ in) (Fig. 10a). THDOC treatment before the restraint stress did not have a significant effect on anxiety-like behavior (time in open arm: $29.5 \pm 7.1 \mathrm{~s}$; distance in open arm: $58.3 \pm 16.5$ in) compared with vehicle-treated mice (time in open arm: $16.9 \pm 5.8 \mathrm{~s}$; distance in open arm: $46.5 \pm 16.2$ in), likely because both these experimental groups exhibit high levels corticosterone (Fig. 6). However, finasteride treatment before restraint stress significantly increased the amount of time spent in the open arm $(80.8 \pm 12.7 \mathrm{~s})$ and increased the distance traveled in the open arm (189.7 \pm 30.5 in) compared with vehicle-treated controls (time in open arm: $16.9 \pm 5.8 \mathrm{~s}$; distance in open arm: $46.5 \pm 16.2$ in) (Fig. 10a) $(n=10-12$ mice per experimental group; significance $p<0.05$ determined using a one-way ANOVA with Bonferroni post hoc test: $F=10.09$; df within-group $=39$; $\mathrm{df}$ between group $=3$ ). Consistent with the anxiolytic effects of finasteride following stress, 5 of 11 finasteride-treated mice crossed from one open arm immediately into the opposite open arm and 2 of 11 animals exhibited rearing in the center of the elevated plus maze. These behaviors were not observed in the other experimental groups. In addition, we found similar anxiolytic effects of finasteride following stress in the open field test. Restraint stress significantly decreased the amount of time spent in the center of the open field (44.1 $\pm 5.7 \mathrm{~s})$ without any change in locomotor behavior (1922 \pm 111.6 beam breaks) compared with controls (time in center: $69.9 \pm 5.0 \mathrm{~s}$; beam breaks: $2067.6 \pm 78.8$ ) (Fig. 10b). THDOC treatment did not significantly alter the time spent in the center of the open field $(63.7 \pm 7.8 \mathrm{~s})$ or the number of beam breaks $(2320.1 \pm 211.3)$ compared with vehicle-treated mice (time in center: $44.1 \pm 5.7 \mathrm{~s}$; beam breaks: $1922 \pm 111.6)$. However, finasteride treatment significantly increased the amount of time spent in the center of the open field (72.1 $\pm 10.4 \mathrm{~s})$ with no change in locomotor behavior $(1979.7 \pm 136.4)$ compared with vehicle-treated mice (time in center: $44.1 \pm 5.7 \mathrm{~s}$; beam breaks: $1922 \pm 111.6)$; (Fig. 10b) $(n=$ $16-19$ mice per experimental group; significance $p<0.05$ determined using a one-way ANOVA with Bonferroni post hoc test: $F=4.599$; df within-group $=55$; df between group $=3$ ). These data indicate that neurosteroidogenesis is required to mediate the anxiety-like behaviors induced by stress.

\section{Discussion}

This is the first study demonstrating that excitatory actions of neurosteroids on $\mathrm{GABA}_{\mathrm{A}} \mathrm{R} \delta$ subunit-containing receptors are required for the physiological response to stress and stressinduced anxiety-like behavior. Our data demonstrate that $\mathrm{CRH}$ neurons are modulated by neurosteroids via actions on $\mathrm{GABA}_{\mathrm{A}} \mathrm{R}$ $\delta$ subunit-containing receptors (Figs. 3,4 ). Consistent with the inhibitory actions of GABA, neurosteroids decrease the firing rate of $\mathrm{CRH}$ neurons under normal conditions by potentiating the effects of GABA on $\mathrm{GABA}_{\mathrm{A}} \mathrm{R} \delta$ subunit-containing receptors (Figs. 4, 7). Interestingly, we discovered that following acute restraint stress, THDOC increases the activity of CRH neurons and increases stress-induced corticosterone levels (Figs. 6, 7). These data indicate that GABA is no longer inhibitory following stress in $\mathrm{CRH}$ neurons and our data reveal the mechanism underlying the collapse of the chloride gradient following stress involving dephosphorylation and downregulation of KCC2.

The inhibitory actions of GABA rely on the maintenance of the chloride gradient, which is largely accomplished by the $\mathrm{K}^{+}$/ $\mathrm{Cl}^{-}$cotransporter (KCC2) in the adult (for review, see Farrant and Kaila, 2007). Here we demonstrate that the collapse in the chloride gradient in $\mathrm{CRH}$ neurons following acute stress depends on the phosphorylation state of KCC2 residue Ser940 and surface expression of KCC2 rather than total KCC2 levels (Fig. 9). Our data provides the underlying mechanism of a previous demonstration of a collapse in the $\mathrm{Cl}^{-}$gradient following stress (Hewitt et al., 2009). Dephosphorylation of KCC2 results in decreased expression of KCC2 on the cell surface (Rivera et al., 2004; Wake et al., 2007; Lee et al., 2011), causing depolarizing and excitatory actions of GABA (Lee et al., 2011). Here we demonstrate for the first time a stress-induced dephosphorylation of KCC2 residue Ser940 and decreased surface expression of KCC2 in the PVN (Fig. 9), resulting in excitatory actions of neurosteroids on $\mathrm{CRH}$ neurons mediated by $\mathrm{GABA}_{\mathrm{A}} \mathrm{R} \delta$ subunit-containing receptors (Fig. 7). These results demonstrate dynamic alterations in the 


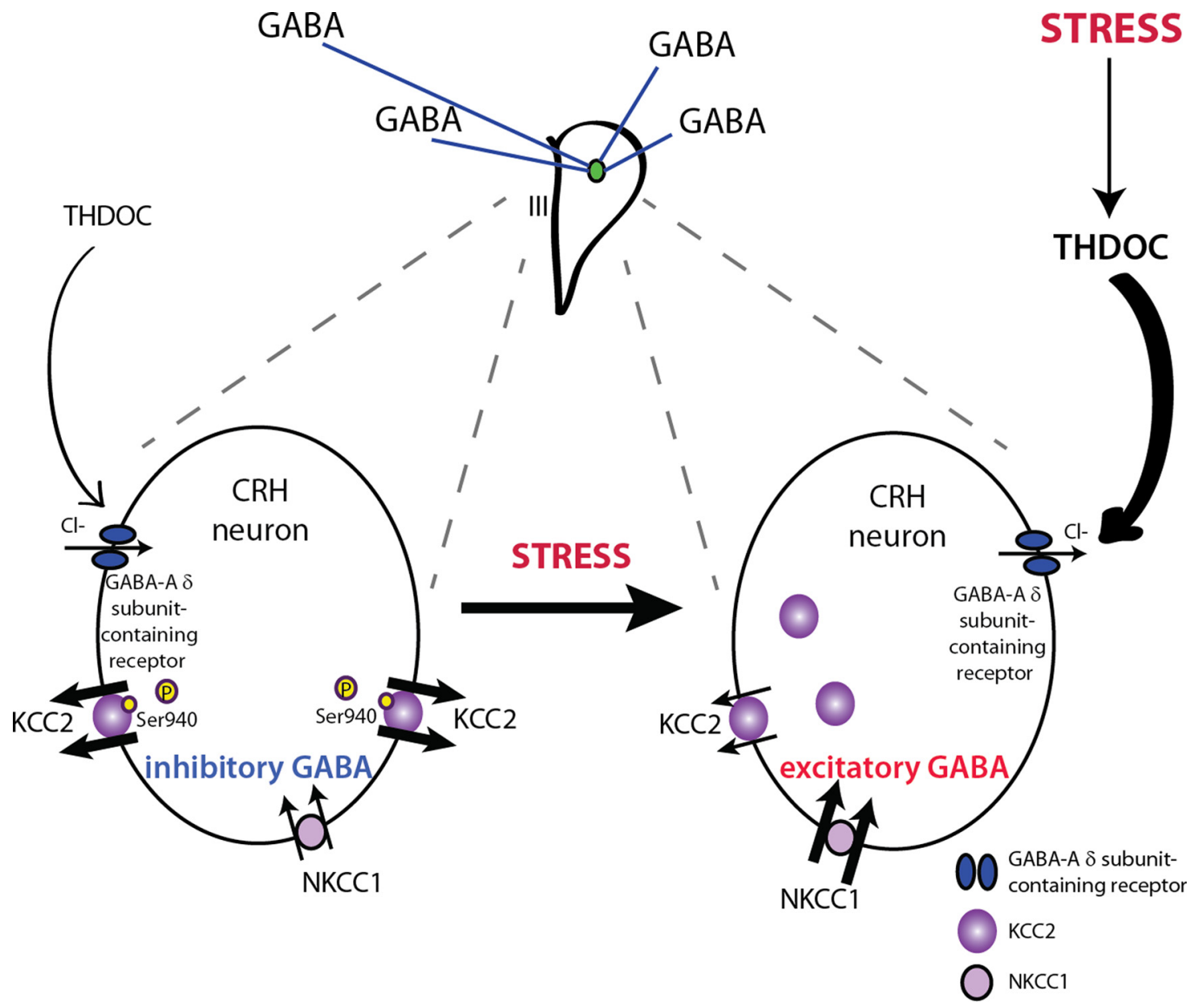

Figure 11. A model of HPA axis regulation. The activity of the HPA axis is governed by CRH neurons in the PVN. These neurons receive inputs from many different brain regions and are modulated by many different neurotransmitter systems. However, the activity of these neurons is ultimately under robust GABAergic control. We propose a model of HPA axis activation which overrides this robust GABAergic inhibition by dephosphorylating and downregulating KCC2, resulting in a collapse in the chloride gradient, and excitatory actions of GABA. The stress-derived neurosteroid, THDOC, potentiates $\mathrm{GABA}_{\mathrm{A}} \mathrm{R} \delta$ subunit-containing receptors, resulting in excitation of CRH neurons which is required to mount the physiological response to stress in a rapid, all-or-none fashion.

phosphorylation state of KCC2 and thus, the extent of GABAergic inhibition under physiological conditions. We propose a model in which dephosphorylation and downregulation of KCC2 is the normal mechanism through which CRH neurons are relieved from robust GABAergic constraint to mount the physiological response to stress (Fig. 11), which may be necessary to override the GABAergic control of the rhythmic, diurnal corticosterone secretion (for review, see Buijs and Kalsbeek, 2001).

In immature neurons, expression of the $\mathrm{Na}^{+}-\mathrm{K}^{+}-\mathrm{Cl}^{-}$ cotransporter, NKCC1, predominates resulting in depolarizing actions of GABA (Ben-Ari, 2002), although, in mature neurons it is argued that depolarizing GABA is likely still inhibitory in hippocampal neurons via shunting inhibition (Staley and Mody, 1992; Banke and McBain, 2006). Deficits in KCC2 have been suggested to result in deficient GABAergic inhibition and contribute to numerous disease states, including ischemia, neuropathic pain, trauma, and epilepsy (Coull et al., 2003; Dzhala et al., 2005; Jin et al., 2005; Prescott et al., 2006; Huberfeld et al., 2007; Papp et al., 2008). Our data suggest that under physiological conditions, such as in response to stress, there is a dynamic regulation of KCC2, resulting in excitatory actions of GABA on CRH neurons. These data support the idea that, in specific populations of adult neurons, GABA can be excitatory under physiological conditions. These findings build on existing evidence that GABA is excitatory in $\mathrm{KCC}^{-1-}$ mice (Hübner et al., 2001), follow- ing spinal cord injury (Nabekura et al., 2002), and in adult human patients with TLE (Cohen et al., 2002; Huberfeld et al., 2007; Muñoz et al., 2007; for review, see Kahle et al., 2008). Thus, it is becoming increasingly apparent that under both physiological and pathological conditions, GABA can be excitatory in specific populations of adult neurons. In addition, the dynamic changes in chloride homeostasis via alterations in KCC2 expression can no longer be ignored when considering the impact of GABAergic inhibition.

GABAergic inhibition has been proposed to play a key role in the regulation of $\mathrm{CRH}$ neurons. Here we demonstrate, for the first time, a role for the $\mathrm{GABA}_{\mathrm{A}} \mathrm{R} \delta$ subunit in the regulation of $\mathrm{CRH}$ neurons, and thus, control of the HPA axis. Previously, $\mathrm{GABA}_{\mathrm{A}} \mathrm{R} \delta$ subunit expression was documented in the PVN of the hypothalamus (Pirker et al., 2000), although these findings have remained controversial merely due to the limited number of studies investigating $\mathrm{GABA}_{\mathrm{A}} \mathrm{R}$ subunit expression in this region. Interestingly, it was discovered that there are changes in the mRNA expression of extrasynaptic $\alpha 5$ - and $\delta$-subunit-containing receptors following chronic stress (Verkuyl et al., 2004), which implicate $\delta$-subunit-containing receptors in stress reactivity. Here we observe the expression of the $\mathrm{GABA}_{\mathrm{A}} \mathrm{R} \delta$ subunit in the PVN using both Western blot and immunohistochemical techniques (Fig. 2). Further, our functional data demonstrate a neurosteroid-sensitive tonic current controlling the activity of CRH neurons (Figs. 3, 4), implicating the involvement of the $\mathrm{GABA}_{\mathrm{A}} \mathrm{R} \delta$ subunit in the regulation of these neurons. Most 
convincing are the data demonstrating a lack of neurosteroid sensitivity in CRH neurons from Gabrd ${ }^{-\prime-}$ mice (Figs. 3, 4). These data support a role for $\mathrm{GABA}_{\mathrm{A}} \mathrm{R} \delta$ subunit-containing receptors in the regulation of the stress response. However, in light of the excitatory actions of GABA on CRH neurons following stress, there must be additional mechanisms functioning to shut down the HPA axis, such as presynaptic changes on the GABA drive onto $\mathrm{CRH}$ neurons (Verkuyl et al., 2005; for review, see Wamsteeker and Bains, 2010). Additional experiments are required to fully understand the impact of excitatory actions of GABA following stress and the implications for the control of the HPA axis.

Our data demonstrate that neurosteroid actions on $\mathrm{GABA}_{\mathrm{A}} \mathrm{Rs}$ are required to mount the physiological response to stress (Fig. 6). This is in contrast to the findings that neurosteroids, including THDOC, are anxiolytic under basal conditions (Crawley et al., 1986; Reddy and Kulkarni, 1997; Rodgers and Johnson, 1998). However, previous studies have demonstrated anxiogenic actions of neurosteroids under conditions of altered steroid hormone levels (Smith et al., 2006), consistent with our findings following stress. It is interesting to note that previous studies have shown that administration of the neurosteroid allopregnanolone also exacerbated the corticosterone response to acute stress (Guo et al., 1995). THDOC levels reach $\sim 15-30 \mathrm{~nm}$ in the plasma following stress and local concentrations of neurosteroids are likely much higher (for review, see Reddy, 2003). In addition to elevations in the stress-derived neurosteroid, THDOC, following stress, there are also elevations in the levels of the ovarian-derived neurosteroid, allopregnanolone (Purdy et al., 1991). Future studies are required to determine the contribution of allopregnanolone to the regulation of the HPA axis. However, since allopregnanolone is also a positive allosteric modulator of $\mathrm{GABA}_{\mathrm{A}} \mathrm{Rs}$, acting preferentially on $\mathrm{GABA}_{\mathrm{A}} \mathrm{R} \delta$ subunit-containing receptors, we predict that allopregnanolone may also contribute to the excitation of CRH neurons.

This study demonstrates a novel role for $\mathrm{GABA}_{\mathrm{A}} \mathrm{R} \delta$ subunitcontaining receptors and phosphorylation of KCC2 residue Ser940 in the regulation of the HPA axis. Although the mechanism of KCC2 dephosphorylation associated with stress is currently unknown, glutamate-mediated dephosphorylation and downregulation of KCC2 has been shown to result in excitatory actions of GABA (Lee et al., 2011). Future studies are required to determine the exact mechanism of stress-induced KCC2 Ser940 dephosphorylation following stress, which may have therapeutic implications for stress-induced anxiety-like behaviors. Information gained from this study, identifying novel targets for HPA axis regulation, may have therapeutic potential in the treatment of many disorders associated with HPA axis malfunction, such as epilepsy, osteoporosis, premature ejaculation, premenstrual syndrome, major depression, and postpartum depression (for review, see Chrousos, 2009).

\section{References}

Banke TG, McBain CJ (2006) GABAergic input onto CA3 hippocampal interneurons remains shunting throughout development. J Neurosci 26:11720-11725.

Barnard EA, Skolnick P, Olsen RW, Mohler H, Sieghart W, Biggio G, Braestrup C, Bateson AN, Langer SZ (1998) International Union of Pharmacology. XV. Subtypes of gamma-aminobutyric acidA receptors: classification on the basis of subunit structure and receptor function. Pharmacol Rev 50:291-313.

Belelli D, Casula A, Ling A, Lambert JJ (2002) The influence of subunit composition on the interaction of neurosteroids with $\mathrm{GABA}(\mathrm{A})$ receptors. Neuropharmacology 43:651-661.

Ben-Ari Y (2002) Excitatory actions of gaba during development: the nature of the nurture. Nat Rev Neurosci 3:728-739.

Boehm SL 2nd, Homanics GE, Blednov YA, Harris RA (2006) delta-Subunit
GABAA receptor knockout mice are less sensitive to the actions of 4,5,6,7tetrahydroisoxazolo-[5,4-c]pyridin-3-ol. Eur J Pharmacol 541:158-162.

Bolte S, Cordelières FP (2006) A guided tour into subcellular colocalization analysis in light microscopy. J Microsc 224:213-232.

Brown N, Kerby J, Bonnert TP, Whiting PJ, Wafford KA (2002) Pharmacological characterization of a novel cell line expressing human alpha(4)beta(3)delta GABA(A) receptors. Br J Pharmacol 136:965974.

Browne SH, Kang J, Akk G, Chiang LW, Schulman H, Huguenard JR, Prince DA (2001) Kinetic and pharmacological properties of GABA(A) receptors in single thalamic neurons and GABA(A) subunit expression. J Neurophysiol 86:2312-2322.

Buijs RM, Kalsbeek A (2001) Hypothalamic integration of central and peripheral clocks. Nat Rev Neurosci 2:521-526.

Chrousos GP (2009) Stress and disorders of the stress system. Nat Rev Endocrinol 5:374-381.

Cohen I, Navarro V, Clemenceau S, Baulac M, Miles R (2002) On the origin of interictal activity in human temporal lobe epilepsy in vitro. Science 298:1418-1421.

Coull JA, Boudreau D, Bachand K, Prescott SA, Nault F, Sík A, De Koninck P, De Koninck Y (2003) Trans-synaptic shift in anion gradient in spinal lamina I neurons as a mechanism of neuropathic pain. Nature 424:938-942.

Crawley JN, Glowa JR, Majewska MD, Paul SM (1986) Anxiolytic activity of an endogenous adrenal steroid. Brain Res 398:382-385.

Decavel C, Van den Pol AN (1990) GABA: a dominant neurotransmitter in the hypothalamus. J Comp Neurol 302:1019-1037.

Dzhala VI, Talos DM, Sdrulla DA, Brumback AC, Mathews GC, Benke TA, Delpire E, Jensen FE, Staley KJ (2005) NKCC1 transporter facilitates seizures in the developing brain. Nat Med 11:1205-1213.

Farrant M, Kaila K (2007) The cellular, molecular and ionic basis of GABA(A) receptor signalling. Prog Brain Res 160:59-87.

Farrant M, Nusser Z (2005) Variations on an inhibitory theme: Phasic and tonic activation of GABA(A) receptors. Nat Rev Neurosci 6:215-229.

Guo AL, Petraglia F, Criscuolo M, Ficarra G, Nappi RE, Palumbo MA, Trentini GP, Purdy RH, Genazzani AR (1995) Evidence for a role of neurosteroids in modulation of diurnal changes and acute stress-induced corticosterone secretion in rats. Gynecol Endocrinol 9:1-7.

Herman JP, Figueiredo H, Mueller NK, Ulrich-Lai Y, Ostrander MM, Choi DC, Cullinan WE (2003) Central mechanisms of stress integration: hierarchical circuitry controlling hypothalamo-pituitary-adrenocortical responsiveness. Front Neuroendocrinol 24:151-180.

Herman JP, Mueller NK, Figueiredo H (2004) Role of GABA and glutamate circuitry in hypothalamo-pituitary-adrenocortical stress integration. Ann N Y Acad Sci 1018:35-45.

Hevers W, Lüddens H (1998) The diversity of GABA(A) receptors-Pharmacological and electrophysiological properties of GABA(A) channel subtypes. Mol Neurobiol 18:35-86.

Hewitt SA, Wamsteeker JI, Kurz EU, Bains JS (2009) Altered chloride homeostasis removes synaptic inhibitory constraint of the stress axis. Nat Neurosci 12:438-443.

Hoyda TD, Samson WK, Ferguson AV (2009) Adiponectin depolarizes parvocellular paraventricular nucleus neurons controlling neuroendocrine and autonomic function. Endocrinology 150:832-840.

Huberfeld G, Wittner L, Clemenceau S, Baulac M, Kaila K, Miles R, Rivera C (2007) Perturbed chloride homeostasis and GABAergic signaling in human temporal lobe epilepsy. J Neurosci 27:9866-9873.

Hübner CA, Stein V, Hermans-Borgmeyer I, Meyer T, Ballanyi K, Jentsch T] (2001) Disruption of KCC2 reveals an essential role of K-Cl cotransport already in early synaptic inhibition. Neuron 30:515-524.

Jin X, Huguenard JR, Prince DA (2005) Impaired $\mathrm{Cl}^{-}$extrusion in layer V pyramidal neurons of chronically injured epileptogenic neocortex. J Neurophysiol 93:2117-2126.

Kahle KT, Staley KJ, Nahed BV, Gamba G, Hebert SC, Lifton RP, Mount DB (2008) Roles of the cation-chloride cotransporters in neurological disease. Nat Clin Pract Neurol 4:490-503.

Kuzmiski JB, Marty V, Baimoukhametova DV, Bains JS (2010) Stressinduced priming of glutamate synapses unmasks associative short-term plasticity. Nat Neurosci 13:1257-1264.

Larsen PJ, Seier V, Fink-Jensen A, Holst JJ, Warberg J, Vrang N (2003) Cocaine- and amphetamine-regulated transcript is present in hypotha- 
lamic neuroendocrine neurones and is released to the hypothalamicpituitary portal circuit. J Neuroendocrinol 15:219-226.

Lee HH, Walker JA, Williams JR, Goodier RJ, Payne JA, Moss SJ (2007) Direct protein kinase C-dependent phosphorylation regulates the cell surface stability and activity of the potassium chloride cotransporter KCC2. J Biol Chem 282:29777-29784.

Lee HH, Jurd R, Moss SJ (2010) Tyrosine phosphorylation regulates the membrane trafficking of the potassium chloride co-transporter KCC2. Mol Cell Neurosci 45:173-179.

Lee HH, Deeb TZ, Walker JA, Davies PA, Moss SJ (2011) NMDA receptor activity downregulates KCC2 resulting in depolarizing GABA(A) receptor-mediated currents. Nat Neurosci 14:736-743.

Luther JA, Daftary SS, Boudaba C, Gould GC, Halmos KC, Tasker JG (2002) Neurosecretory and non-neurosecretory parvocellular neurones of the hypothalamic paraventricular nucleus express distinct electrophysiological properties. J Neuroendocrinol 14:929-932.

Maguire J, Mody I (2007) Neurosteroid synthesis-mediated regulation of GABA(A) receptors: relevance to the ovarian cycle and stress. J Neurosci 27:2155-2162.

Maguire JL, Stell BM, Rafizadeh M, Mody I (2005) Ovarian cycle-linked changes in $\mathrm{GABA}(\mathrm{A})$ receptors mediating tonic inhibition alter seizure susceptibility and anxiety. Nat Neurosci 8:797-804.

Maguire J, Ferando I, Simonsen C, Mody I (2009) Excitability changes related to GABAA receptor plasticity during pregnancy. J Neurosci 29:9592-9601.

Mihalek RM, Banerjee PK, Korpi ER, Quinlan JJ, Firestone LL, Mi ZP, Lagenaur C, Tretter V, Sieghart W, Anagnostaras SG, Sage JR, Fanselow MS, Guidotti A, Spigelman I, Li Z, DeLorey TM, Olsen RW, Homanics GE (1999) Attenuated sensitivity to neuroactive steroids in gammaaminobutyrate type A receptor delta subunit knockout mice. Proc Natl Acad Sci U S A 96:12905-12910.

Mody I, Pearce RA (2004) Diversity of inhibitory neurotransmission through GABAA receptors. Trends Neurosci 27:569-575.

Mortensen M, Ebert B, Wafford K, Smart TG (2010) Distinct activities of GABA agonists at synaptic- and extrasynaptic-type GABAA receptors. J Physiol 588:1251-1268.

Muñoz A, Méndez P, DeFelipe J, Alvarez-Leefmans FJ (2007) Cationchloride cotransporters and GABA-ergic innervation in the human epileptic hippocampus. Epilepsia 48:663-673.

Nabekura J, Ueno T, Okabe A, Furuta A, Iwaki T, Shimizu-Okabe C, Fukuda A, Akaike N (2002) Reduction of KCC2 expression and GABAA receptor-mediated excitation after in vivo axonal injury. J Neurosci 22:4412-4417.

Papp E, Rivera C, Kaila K, Freund TF (2008) Relationship between neuronal vulnerability and potassium-chloride cotransporter 2 immunoreactivity in hippocampus following transient forebrain ischemia. Neuroscience 154:677-689.

Park JB, Skalska S, Son S, Stern JE (2007) Dual GABAA receptor-mediated inhibition in rat presympathetic paraventricular nucleus neurons. J Physiol 582:539-551.

Payne JA, Rivera C, Voipio J, Kaila K (2003) Cation-chloride co-transporters in neuronal communication, development and trauma. Trends Neurosci 26:199-206.

Pirker S, Schwarzer C, Wieselthaler A, Sieghart W, Sperk G (2000) GABA(A) receptors: Immunocytochemical distribution of 13 subunits in the adult rat brain. Neuroscience 101:815-850.

Prescott SA, Sejnowski TJ, De KoninckY (2006) Reduction of anion reversal potential subverts the inhibitory control of firing rate in spinal lamina I neurons: towards a biophysical basis for neuropathic pain. Mol Pain 2:32.

Purdy RH, Morrow AL, Moore PH Jr, Paul SM (1991) Stress-induced elevations of gamma-aminobutyric-acid type-A receptor-active steroids in the rat-brain. Proc Natl Acad Sci U S A 88:4553-4557.

Reddy DS (2003) Is there a physiological role for the neurosteroid THDOC in stress-sensitive conditions? Trends Pharmacol Sci 24:103-106.

Reddy DS, Kulkarni SK (1997) Differential anxiolytic effects of neurosteroids in the mirrored chamber behavior test in mice. Brain Res 752:61-71.

Rivera C, Voipio J, Payne JA, Ruusuvuori E, Lahtinen H, Lamsa K, Pirvola U, Saarma M, Kaila K (1999) The $\mathrm{K}^{+} / \mathrm{Cl}^{-}$co-transporter KCC2 renders GABA hyperpolarizing during neuronal maturation. Nature 397:251-255.

Rivera C, Voipio J, Thomas-Crusells J, Li H, Emri Z, Sipilä S, Payne JA, Minichiello L, Saarma M, Kaila K (2004) Mechanism of activitydependent downregulation of the neuron-specific $\mathrm{K}-\mathrm{Cl}$ cotransporter KCC2. J Neurosci 24:4683-4691.

Rivera C, Voipio J, Kaila K (2005) Two developmental switches in GABAergic signalling: the $\mathrm{K}^{+}-\mathrm{Cl}^{-}$cotransporter $\mathrm{KCC} 2$ and carbonic anhydrase CAVII. J Physiol 562:27-36.

Rodgers RJ, Johnson NJ (1998) Behaviorally selective effects of neuroactive steroids on plus-maze anxiety in mice. Pharmacol Biochem Behav 59:221-232.

Smith SS, Ruderman Y, Frye C, Homanics G, Yuan M (2006) Steroid withdrawal in the mouse results in anxiogenic effects of 3alpha,5beta-THP: a possible model of premenstrual dysphoric disorder. Psychopharmacology (Berl) 186:323-333.

Spigelman I, Li Z, Liang J, Cagetti E, Samzadeh S, Mihalek RM, Homanics GE, Olsen RW (2003) Reduced inhibition and sensitivity to neurosteroids in hippocampus of mice lacking the GABA(A) receptor delta subunit. J Neurophysiol 90:903-910.

Staley KJ, Mody I (1992) Shunting of excitatory input to dentate gyrus granule cells by a depolarizing GABAA receptor-mediated postsynaptic conductance. J Neurophysiol 68:197-212.

Stell BM, Brickley SG, Tang CY, Farrant M, Mody I (2003) Neuroactive steroids reduce neuronal excitability by selectively enhancing tonic inhibition mediated by delta subunit-containing GABA(A) receptors. Proc Natl Acad Sci U S A 100:14439-14444.

Ulrich-Lai YM, Herman JP (2009) Neural regulation of endocrine and autonomic stress responses. Nat Rev Neurosci 10:397-409.

Verkuyl JM, Hemby SE, Joëls M (2004) Chronic stress attenuates GABAergic inhibition and alters gene expression of parvocellular neurons in rat hypothalamus. Eur J Neurosci 20:1665-1673.

Verkuyl JM, Karst H, Joëls M (2005) GABAergic transmission in the rat paraventricular nucleus of the hypothalamus is suppressed by corticosterone and stress. Eur J Neurosci 21:113-121.

Wake H, Watanabe M, Moorhouse AJ, Kanematsu T, Horibe S, Matsukawa N, Asai K, Ojika K, Hirata M, Nabekura J (2007) Early changes in KCC2 phosphorylation in response to neuronal stress result in functional downregulation. J Neurosci 27:1642-1650.

Wamsteeker JI, Bains JS (2010) A synaptocentric view of the neuroendocrine response to stress. Eur J Neurosci 32:2011-2021.

Whiting PJ, Bonnert TP, McKernan RM, Farrar S, Le Bourdelles B, Heavens RP, Smith DW, Hewson L, Rigby MR, Sirinathsinghji DJ, Thompson SA, Wafford KA (1999) Molecular and functional diversity of the expanding GABA-A receptor gene family. Ann N Y Acad Sci 868:645-653.

Wohlfarth KM, Bianchi MT, Macdonald RL (2002) Enhanced neurosteroid potentiation of ternary $\mathrm{GABA}(\mathrm{A})$ receptors containing the delta subunit. J Neurosci 22:1541-1549. 